Bradleya 30/2012

pages $65-92$

\title{
The genus Aloe L. (Asphodelaceae: Alooideae) in Malawi
}

\author{
Ronell R. Klopper ${ }^{1}$, Stewart S. Lane², Gladys Msekandiana-Mkwapatira ${ }^{3}$ and \\ Gideon F. Smith ${ }^{4}$
}

${ }^{1}$ Biosystematics Research and Biodiversity Collections Division, South African National Biodiversity Institute, Private Bag X101, Pretoria 0002, South Africa / H.G.W.J. Schweickerdt Herbarium, Department of Plant Science, University of Pretoria, Pretoria 0002, South Africa (email: R.Klopper@sanbi.org.za, author for correspondence).

2 P.O. Box 354, Derdepark 0035, South Africa (email: StewartLane36@yahoo.co.uk).

${ }^{3}$ National Herbarium and Botanic Gardens of Malawi, P.O. Box 528, Zomba, Malawi (email: gladyscm2000@yahoo.co.uk).

${ }^{4}$ Office of the Chief Director: Biosystematics Research and Biodiversity Collections, South African National Biodiversity Institute, Private Bag X101, Pretoria 0002, South Africa / H.G.W.J. Schweickerdt Herbarium, Department of Plant Science, University of Pretoria, Pretoria 0002, South Africa / Centre for Functional Ecology, Departamento de Ciências da Vida, Universidade de Coimbra, 3001-455 Coimbra, Portugal (email: G.Smith@sanbi.org.za).

Summary: Malawi is a landlocked country situated in the eastern section of South Tropical Africa. This relatively small country has a rich mosaic of habitats owing to the varied topography, altitudinal ranges and rainfall found in different areas. Malawi harbours at least 21 different aloes, three of which are endemic to the country. Aloes in Malawi are severely threatened by habitat destruction and many species are in dire need of conservation. A key to the aloes of Malawi is provided, as well as a description, illustration, distribution map and information on habitat, flowering time, and conservation status for each of the species.

Zusammenfassung: Malawi ist ein Land ohne Meereszugang im östlichen Teil des südlichen tropischen Afrikas. Das relativ kleine Land hat bedingt durch variable Topographie und Höhenlagen sowie unterschiedliche Regenmengen ein reiches Mosaik verschiedener Habitate. In Malawi sind mindestens 21 Aloe-Arten heimisch, von welchen drei für das Land endemisch sind. Die Aloe-Arten Malawis sind durch Habitatzerstörung stark gefährdet, und zahlreiche Arten bedürfen dringend Schutzmassnahmen. Es wird ein Schlüssel zu den malawischen Arten gegeben, sowie für jede Arte Beschreibung, Abbildung, Verbreitungskarte und Angaben zu Standort, Blütezeit, und Gefährdungsstatus.

Introduction to Malawi

Although the area was inhabited by modern humans since the 10th century, some of the oldest prehistoric dinosaur and hominid remains in Africa have been found in the Karonga District of Malawi (Reuters, 2009). The country was officially established in 1891 as the British Protectorate of Nyasaland. For mainly political reasons Britain linked Nyasaland with Northern and Southern Rhodesia (now Zambia and Zimbabwe, respectively) in the Central African Federation in 1953. The Federation was dissolved in 1963. Nyasaland gained independence on $6^{\text {th }}$ July 1964 and was renamed Malawi (The World Fact Book, 2010; http://en.wikipedia.org/wiki/Malawi).

Malawi is a landlocked country situated in the eastern section of South Tropical Africa and is bordered by Mozambique and Tanzania in the east and by Mozambique and Zambia in the west. Malawi is a narrow, north-south extending country of $860 \mathrm{~km}$ long and $90-200 \mathrm{~km}$ wide and is positioned between $9^{\circ} 25^{\prime}$ and $17^{\circ} 08^{\prime} \mathrm{S}$, and $33^{\circ}$ and $36^{\circ} \mathrm{E}$. Three-quarters of its eastern border is made up of the country's most prominent physical feature, the $587 \mathrm{~km}$ long and $85 \mathrm{~km}$ wide Lake Malawi (Lake Nyasa). The southern end of the Great Rift Valley runs through the country from north to south and in Malawi the Rift depression is occupied by Lake Malawi, the narrow Lakeshore plains and the valley of the Shire River. Malawi occupies a total of $118,000 \mathrm{~km}^{2}$, of which $94,276 \mathrm{~km}^{2}$ is land and $23,724 \mathrm{~km}^{2}$ (over $20 \%$ ) is fresh water (Chapman \& White, 1970; DowsettLemaire, 2001a; Msekandiana \& Mlangeni, 2002; The World Fact Book, 2010; http://en.wikipedia. org/wiki/Malawi). 


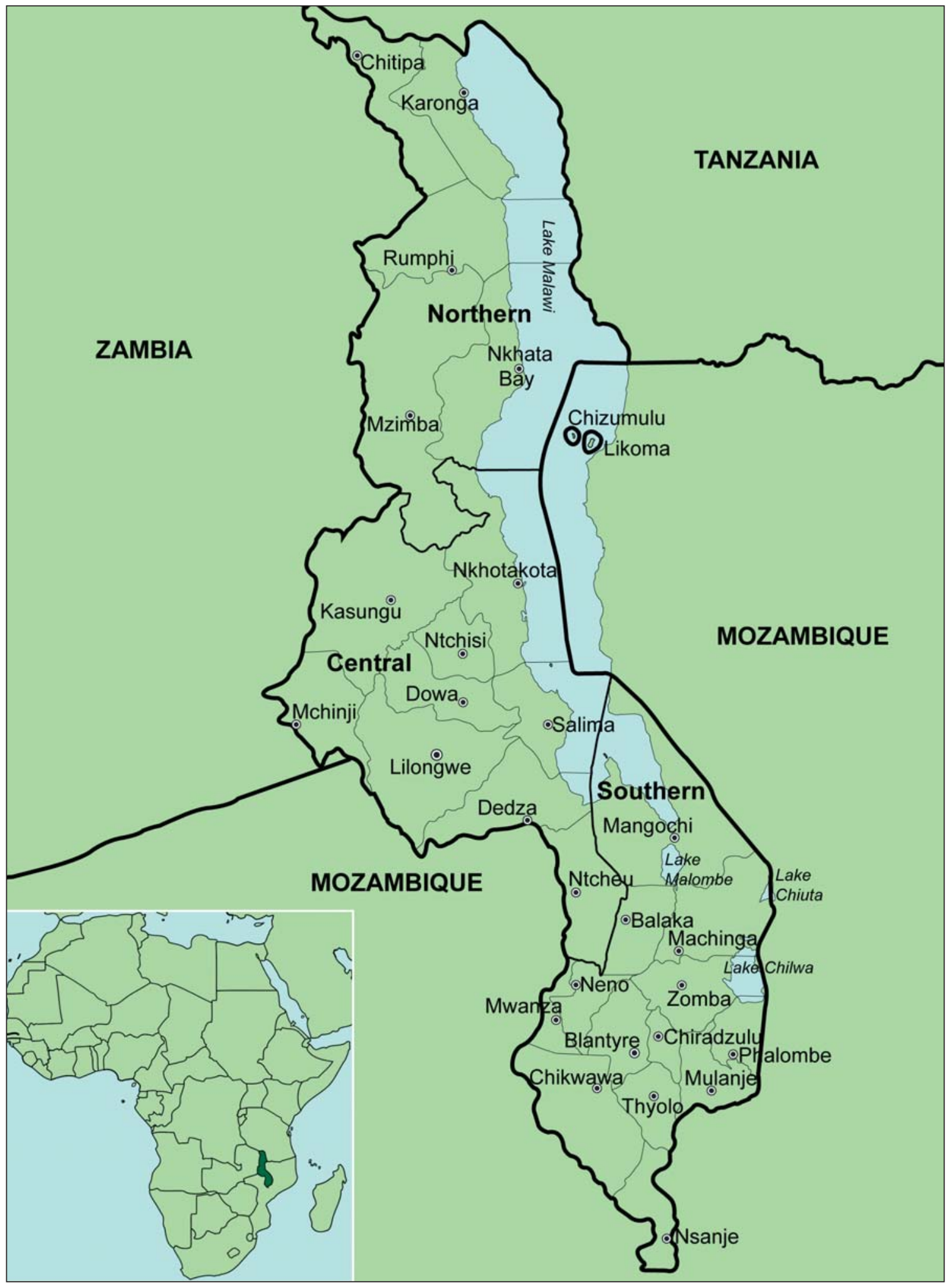

Figure 1. Map of Malawi showing the provinces and districts. 
The lowest point in Malawi is $37 \mathrm{~m}$ above sea level (asl). This is where the Shire River, which flows from the south end of Lake Malawi, crosses the border into Mozambique before it joins the lower reaches of the Zambezi River further south. The northern part of the country is occupied by the Central African peneplain (1,000-1,100 m asl). Several isolated hills and elevated plateaux rise above this plain, e.g. the Misuku Hills (peak at $\pm 2,050 \mathrm{~m})$, the Nyika Plateau $(2,606 \mathrm{~m})$, the North Viphya Plateau $(2,058 \mathrm{~m})$, the South Viphya Plateau (1,954 m) and the Dedza Mountain $(2,198 \mathrm{~m})$. In the southern part of the country the peneplain lies at 500-600 m asl. Here the highland areas are less extensive, but more prominent, e.g. the Shire Highlands reach to 2,085 $\mathrm{m}$ at Zomba and at 3,002 $\mathrm{m}$ asl Mount Mulanje is the highest point in the country, and the highest in south-central Africa. Lake Malawi is situated at $460 \mathrm{~m}$ asl and has a maximum depth of $700 \mathrm{~m}$. The Great Rift Valley is surrounded by mountainous areas (910-1,200 $\mathrm{m}$ asl) and to the south of Lake Malawi is the gently undulating and rolling plateau of the Shire Highlands $( \pm 910 \mathrm{~m})$ (Dowsett-Lemaire, 2001a; The World Fact Book, 2010; http://en.wikipedia.org/wiki/ Malawi).

Malawi has a continental climate with large seasonal temperature variations. The altitude of the country moderates what would otherwise be an equatorial climate. In the southern, low-lying areas the climate is hot with mean annual temperatures of $24^{\circ}-25^{\circ} \mathrm{C}$, while it is temperate in the northern highlands $\left(18^{\circ}-21^{\circ} \mathrm{C}\right)$ and even cool $\left(13^{\circ}-15^{\circ} \mathrm{C}\right)$ at elevations above $2,000 \mathrm{~m}$. The summer rainy season is between November and April when the temperature is warm and equatorial rains and thunderstorms are experienced. Rainfall and severity of storms reaches a peak in late March. Thereafter rainfall rapidly diminishes into the dry season (between May to September). Moist maritime air from the Mozambique Channel reaches Malawi and causes so-called chiperone weather: periodic spells of mist, drizzle or even rain in the dry season. Mean annual rainfall varies considerably between different parts of the country: from $\pm 700 \mathrm{~mm}$ in certain areas to over $3,000 \mathrm{~mm}$ at the mouth of the Songwe River on the Tanzanian border (Chapman \& White, 1970; Dowsett-Lemaire, 2001a; http://en.wikipedia.org/ wiki/Malawi).

The varied topography, altitudinal range (37$3,002 \mathrm{~m}$ ) and rainfall present in Malawi are reflected in the rich mosaic of habitats found in this relatively small country. The vegetation predominantly consists of miombo woodland, with various types of Zambezian woodland and deciduous forest or thicket dominating the vegetation at low and medium altitudes, as found on the Lake-shore plains, the Shire Valley and the Central African plateau. Evergreen forests are only found along stream banks and rain forest is confined to small areas of high rainfall. These forests form part of the Eastern forest region and have a strong Guineo-Congolian affinity. Grasslands are at their most extensive on the high plateau, while most of the hills and mountainous areas that rise above the peneplain carry some evergreen Afromontane forest. Lowland forest patches are found on the shores of the northern part of Lake Malawi, the Nyika Plateau and the lower slopes of Mt Mulanje. Within the Afromontane region (mainly above 1,500-1,600 m) one finds evergreen bushland/thicket and shrubland. Extensive swamps occur around Lake Chilwa and in the Lower Shire Valley (Dowsett-Lemaire, 2001b; Msekandiana \& Mlangeni, 2002).

Three Regional Centres of Endemism (RCE) (an area with more than $50 \%$ of its phanerogamic species confined to it and harbouring more than 1,000 endemic species) are present in Malawi. The country lies entirely within the Zambezian RCE, one of the richest in its species diversity. The high-altitude peaks form part of the Afromontane Archipelago-like RCE. As with the Afromontane RCE, the Eastern Regional Mosaic has a discontinuous distribution in the lowland forest areas of Malawi (Dowsett-Lemaire, 2001a). Key areas of high endemism include Mt. Mulanje in the south and the Nyika Plateau in the north (Msekandiana \& Mlangeni, 2002; Burrows \& Willis, 2005).

Malawi harbours approximately 5,000-6,000 plant species (Msekandiana \& Mlangeni, 2002). A preliminary Red Data List assessment listed a total of 248 taxa in Malawi of which \pm 128 taxa $(50 \%)$ were regarded as threatened (Critically Endangered, Endangered or Vulnerable). Of the 248 taxa listed, a total of $\pm 114(50 \%)$ are regarded as endemic, and a further 31 (13\%) as near-endemic, to the country (Msekandiana \& Mlangeni, 2002).

\section{Malawian aloes}

The predominantly African genus Aloe comprises a total of almost 600 taxa with an exclusive Old World distribution (Carter et al., 2011). It is a conspicuous component of many African landscapes and Malawi is no exception. The country harbours a total of 21 aloes of which three (14\%) are endemic and a further three (14\%) nearendemic (Table 1).

Additionally, Lane (2004) treats at least nine forms or possible new taxa, which are insufficiently known. These are often only known from 
Table 1. Checklist of endemic and near-endemic Aloe taxa of Malawi, as well as an indication of their threatened status in the country (E - endemic; NE - near endemic; CR - critically endangered; EN - endangered; VU - vulnerable; LC - least concern).

\begin{tabular}{|l|c|c|c|c|c|c|}
\hline Species & E & NE & CR & EN & VU & LC \\
\hline A. arborescens & & & & & $\bullet$ & \\
\hline A. buchananii & & $\bullet$ & & $\bullet$ & & \\
\hline A. bulbicaulis & & & & & $\bullet$ & \\
\hline A. cameronii var. cameronii & & & & & $\bullet$ & \\
\hline A. cameronii var. dedzana & $\bullet$ & & $\bullet$ & & & \\
\hline A. canis & $\bullet$ & & $\bullet$ & & & \\
\hline A. chabaudii var. chabaudii & & & $\bullet$ & & & \\
\hline A. chabaudii var. mlanjeana & $\bullet$ & & $\bullet$ & & & \\
\hline A. christianii & & & & & & $\bullet$ \\
\hline A. cryptopoda & & & & & $\bullet$ & \\
\hline A. duckeri & & & & & $\bullet$ & \\
\hline A. excelsa var. breviflora & & $\bullet$ & $\bullet$ & & & \\
\hline A. greatheadii & & & $\bullet$ & & & \\
\hline A. lateritia var. lateritia & & & $\bullet$ & & & \\
\hline A. mawii & & & & & $\bullet$ & \\
\hline A. menyharthii subsp. menyharthii & & $\bullet$ & & & $\bullet$ & \\
\hline A. myriacantha & & & & & $\bullet$ & \\
\hline A. mzimbana & & & & & $\bullet$ & \\
\hline A. nuttii & & & & & $\bullet$ & \\
\hline A. suffulta & & & $\bullet$ & & & \\
\hline A. zebrina & & & & $\bullet$ & & \\
\hline Total: $\mathbf{2 1}$ & $\mathbf{3}$ & $\mathbf{8}$ & $\mathbf{2}$ & $\mathbf{1 0}$ & $\mathbf{1}$ \\
\hline
\end{tabular}

one plant or a single locality and some can no longer be located in the wild, being only known from cultivation. This makes it difficult or impossible to determine if these plants represent remnants of a larger population or if they are possible hybrids (Lane, 2004). For this reason, these aloes are not included in this treatment.

This contribution provides a complete and updated floristic treatment of the aloes of Malawi. Species descriptions are based on the abbreviated description template as used by the Aloes of the World Project (Smith et al., 2008). These have been simplified as far as possible to capture a broader audience and to make the treatment as user-friendly as possible. In addition, we present an identification key to the aloes of Malawi, along with a series of species-level distribution maps and accompanying images. It is important to bear in mind that the distribution maps were compiled from both historical and current distribution records, and that certain localities indicated on these maps might have been lost through habitat destruction.

\section{History of Aloe discovery in Malawi}

Only eight of the 21 aloes currently recognised in Malawi have their type localities within this country. The other thirteen aloes have their type localities in Angola, Botswana, Tanzania (one taxon each), South Africa, Zambia, Zimbabwe (two taxa each) and Mozambique (four taxa). Although several of the major investigators of aloes have visited Malawi, their visits were mostly brief and their observations sometimes hasty and often based on unrepresentative samples and overly dependent on often inaccurate reports of local residents (Lane, 2004). Some of the important collectors of aloes in Malawi and the periods during which they collected in the country are: J. Buchanan (1891-1896), G.F. Scott Elliot (1894), K.J. Cameron (1896-1899, 1905), B.D. Burtt (1936), I.B. Pole Evans and J. Erens (1930, 1938), 
R.H. Everett (1913), H.C. Ducker, H.B. Christian (1938), J. Smuts and J. Hutchinson (1938), G.W. Reynolds $(1952,1958)$ and S.S. Lane $(1970$ s onwards) (Reynolds, 1954; Exell, 1960; Gillett, 1962; White, 1962; Wild, 1962; Lane, 2004).

The first aloe to be described from Malawi was collected on the Shire Highlands by John Buchanan (1855-1896) in 1892. This aloe was named after Buchanan by Baker (1895) who described it as A. buchananii Baker (Reynolds, 1954; Exell, 1960; Willd, 1962). In 1894, Kenneth J. Cameron (c. 1862-1918) collected an aloe in Malawi and sent the material to Kew where it flowered in 1903. It was subsequently named after Cameron by Hemsley (1903) as A. cameronii Hemsl. (Reynolds, 1954; Exell, 1960; Willd, 1962). Reynolds (1954) suggested that the type locality may be near Blantyre. However, A. cameronii does not occur near Blantyre and it is more likely that it was collected by Cameron from Namadzi Estate, near Zomba. Reynolds (1966) also alluded to this possibility. Following description of this novelty, it took 35 years before the next aloe was described from Malawi.

In June of 1913 Major R.H. Everett collected an aloe from the slopes of Mt. Mulanje. This plant

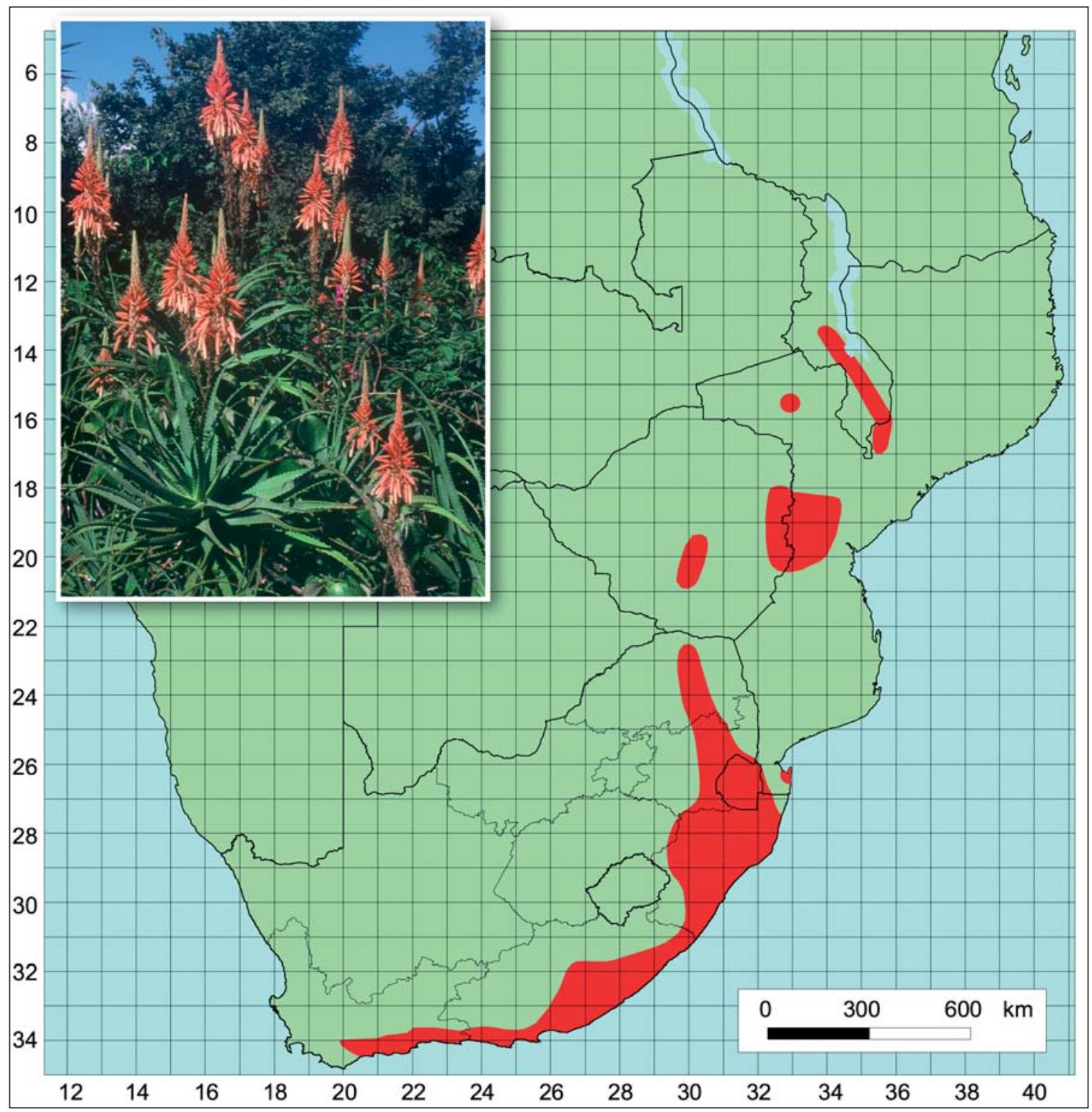

Figure 2. A. arborescens. 
was cultivated and eventually described in 1938 by Harold Basil Christian (1871-1950) as A. chabaudii var. mlanjeana Christian (1938). In June of 1938 Christian collected an aloe on the Zomba Plateau which he later described as A. mawii Christian (1940) (Reynolds, 1954). Bernard Dearman Burtt (1902-1938) travelled to Nyasaland in 1936 to investigate the spread of tse-tse fly in the country (White, 1962). During this expedition he obtained plants from H.C. Ducker that originated from the Livingstonia Mission in northern Malawi. This was subsequently described by Christian (1940) as A. duckeri Christian (Reynolds, 1954). During the Pole Evans Central and East African Expedition in 1938, Illtyd Buller Pole Evans (1879-1968) and Jan Erens (1911-1982) collected several aloe plants that were planted in the gardens of the Division of Botany (at the time near the Union Buildings) in Pretoria, South Africa. Amongst these were plants from Mzimba in the Northern Province of Malawi, which were described as A. mzimbana Christian in 1941 (Verdoorn \& Christian, 1941; Gillett, 1962).

Another twenty-four years passed before Gilbert Westacot Reynolds (1895-1967) described A. cameronii Hemsl. var. dedzana Reynolds from material collected in 1942 by Christian on the Dedza Mountain (Reynolds, 1965). Thirty-six years later, in 2001, Stewart S. Lane (1936-) described $A$. canis Lane from material collected in the Senga Hills by Theo Campbell-Barker. This plant is only known from a few cultivated specimens and could not be relocated in the wild (Lane, 2001; Lane et al., 2003; Lane, 2004).

There is not a lot of literature available on Malawian aloes. The first major work published on these fascinating plants in Malawi is The Aloes of Nyasaland by Gilbert W. Reynolds (1954). Thereafter it took 50 years before the next publication appeared, namely A Field guide to the Aloes of Malawi by one of us (Lane, 2004). During this time only two new aloes were described from Malawi. Prior to these publications there was not a lot of interest in the aloes of Malawi, simply because very little was (and in many cases still is) known about them.

Aloe investigation in Malawi is hampered by several factors, the most important of which is probably continuous habitat transformation and destruction, which has resulted in many isolated populations (often in remote and inaccessible areas). Furthermore, many areas have never been properly surveyed (Lane, 2004). It would therefore not be surprising if new aloes are discovered in Malawi once these under-collected areas are studied.

\section{Conservation and protection status}

Aloes are not protected in the environmental legislation of Malawi. However, all species of Aloe [excluding the widely cultivated $A$. vera (L.) Burm.f.] appear on CITES (Convention on the International Trade in Endangered Species of Wild Fauna and Flora) Appendices, meaning that trade in wild collected aloes is controlled to prevent utilisation that would be incompatible with their survival. All 21 Malawian aloes are listed on Appendix II (CITES, 2010).

Malawi is one of the most densely populated countries in sub-Saharan Africa. The economy of the largely rural population is heavily based on agriculture, with $\pm 85 \%$ of the country's people dependent on subsistence farming. It is thus no surprise that human impact has greatly modified much of the original vegetation of the country. Malawi also has the highest rate of deforestation in southern Africa, with an estimated 3.4\% of its forest lost annually. Extensive areas of lowland rainforests were lost in the early 20th century owing to commercial crop establishment, while the rapid destruction of mid-altitude and Afromontane forests is currently ongoing (Dowsett-Lemaire, 2001a; Msekandiana \& Mlangeni, 2002).

Nearly all aloes in Malawi are threatened to some extent, primarily because of habitat destruction and medicinal use. The most threatened taxa occur in low-lying grasslands, while those inhabiting upland or rocky areas are least threatened. Many areas that previously had large populations of aloes now only have a few plants or none at all (Lane, 2004).

Conservation status and threats to the survival of each species in Malawi are given here according to Msekandiana \& Mlangeni (2002), who used the 1994 IUCN Red List categories (IUCN, 1994). Conservation status in Malawi for taxa not appearing in the 2002-list are given here for the first time, based on personal experience by one of the authors (GM). A total of 20 (95\%) of the 21 aloe taxa occurring in Malawi are regarded as taxa of conservation concern. Of these ten (47.5\%) are regarded as Vulnerable, two (9.5\%) as Endangered and eight (38\%) as Critically Endangered.

\section{Species descriptions \\ ${ }^{\mathrm{E}}$ indicates taxa that are endemic to Malawi. \\ ${ }_{\mathrm{NE}}$ indicates taxa that are near-endemic to Malawi. \\ ? indicates a taxon of uncertain, but possible, occurrence in Malawi.}

\section{Aloe arborescens Mill.}

Common names: krantz aloe; chinthembwe (Chinyanja); chiwiriwiri (Chitumbuka); sayyan (seKone). 

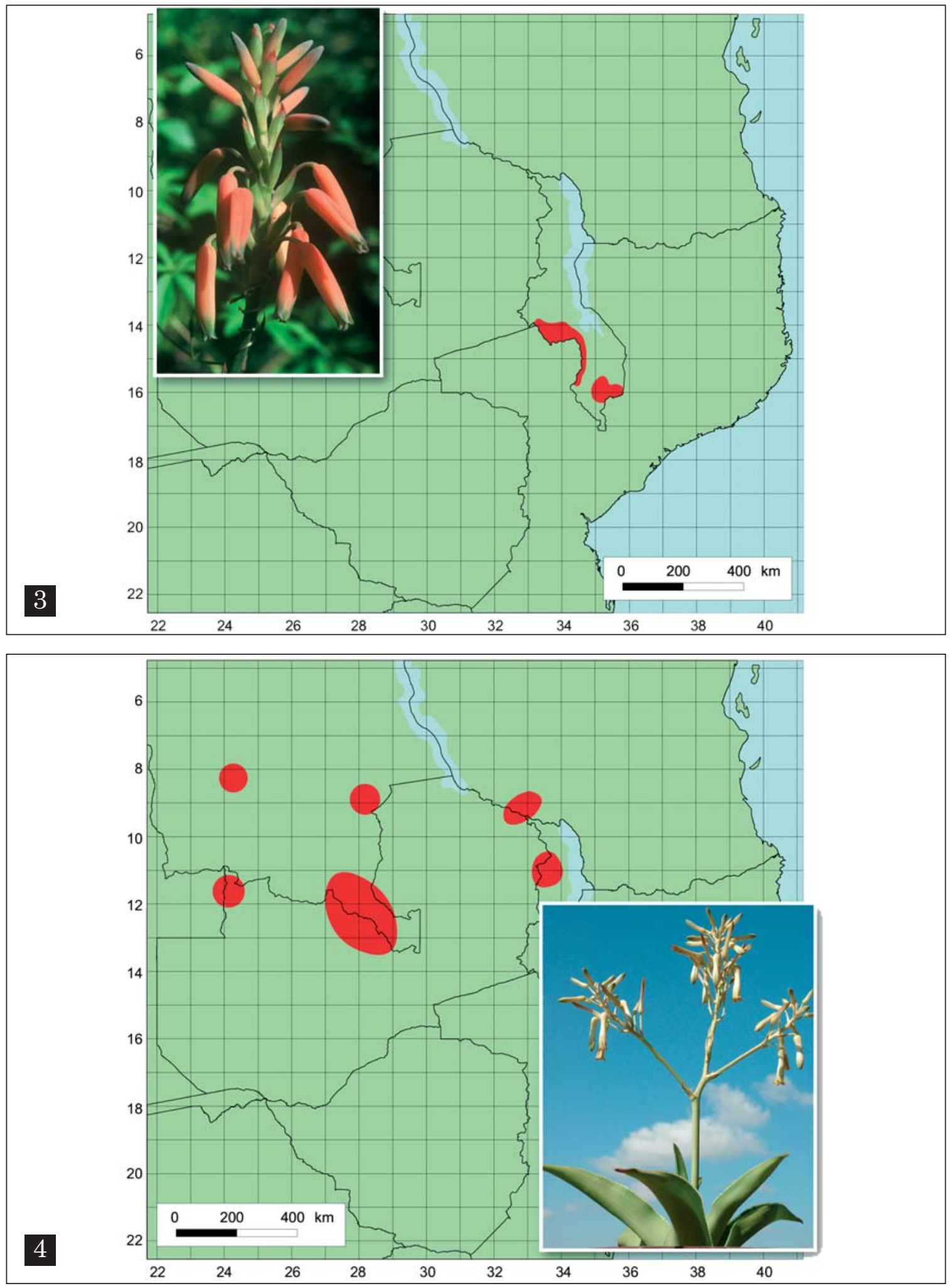

Figure 3. A. buchananii. Figure 4. A. bulbicaulis. 
Key to the aloes of Malawi

1a. Leaf bases enlarged below ground to form bulb-like swelling

1b. Leaf bases not enlarged below ground to form bulb-like swelling

A. bulbicaulis

2a. Leaves grass-like, less than $2 \mathrm{~cm}$ wide

2b. Leaves not grass-like, broader than $2.5 \mathrm{~cm}$

3a. Leaves mostly distichous

3b. Leaves rosulate

4a. Leaves distinctly keeled; flowers $\pm 20 \mathrm{~mm}$ long, with distinctly bilabiate, upturned mouth

4b. Leaves canaliculate; flowers $35-42 \mathrm{~mm}$ long, with mouth not bilabiate or upturned

\section{A. myriacantha}

nuttii

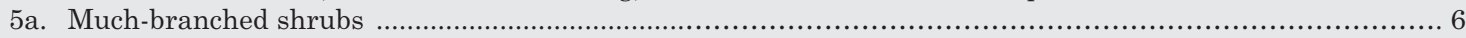

5b. Acaulescent or short stemmed plants, or plants with tall, unbranched stems ..................................... 7

6a. Floral bracts 15-20 $\mathrm{mm}$ long; pedicels green, 35-40 $\mathrm{mm}$ long; flowers with outer perianth segments free to base

A. arborescens

6b. Floral bracts up to $3 \mathrm{~mm}$ long; pedicels reddish brown, up to $8 \mathrm{~mm}$ long; flowers with outer perianth segments free for $12-15 \mathrm{~mm}$

A. cameronii

7a. Stems longer than $1 \mathrm{~m}$, erect, simple or branched above middle

7b. Stems absent or usually shorter than $0.5 \mathrm{~m}$, rosettes solitary or suckering from base

8a. Stems usually branched above middle; racemes with secund flowers

8b. Stems usually simple; racemes with flowers not secund

A. mawii

9a. Leaves with few scattered elliptical spots at base on both su............................................... 9 inflorescence 4-5-branched; racemes up to $14 \times 5 \mathrm{~cm}$ wide; flowers $\pm 34 \mathrm{~mm}$ long...

A. canis

9b. Leaves without spots; inflorescence with up to 15 branches; racemes $20-30 \times 11 \mathrm{~cm}$ wide; flowers $\pm 20 \mathrm{~mm}$ long

A. excelsa var. breviflora

10a. Leaves cauline dispersed with striatulate sheaths of 5-10 mm long; inflorescence slender, climbing and supported by surrounding bushes

A. suffulta

10b. Leaves rosulate with sheaths not prominently visible; inflorescence not slender and climbing, selfsupporting

11a. Flowers not constricted above ovary

11

11b. Flowers slightly or conspicuously constricted above ovary, often forming a globose basal swelling .............. 13

12a. Inflorescence 2-3 m high, 6-10-branched; floral bracts 8-10 mm long; pedicels 8-20 mm long; flowers coral pink with a bloom, 35-45 mm long, outer segments free for $15 \mathrm{~mm}$

A. christianii

12b. Inflorescence 1.00-1.75 m high, 1-4-branched; floral bracts 10-15 mm long; pedicels 15-20 mm long; flowers bright scarlet or orange-scarlet, paler to yellowish-tipped at maturity, glossy, 28-35 mm long, outer segments free to base

13a. Lower leaf surface usually paler than upper surface

A. cryptopoda

13b. Lower and upper leaf surface usually the same colour

14a. Racemes cylindric-acuminate; pedicels $12-18 \mathrm{~mm}$ long; flowers dull flesh pink, 25-32 mm long

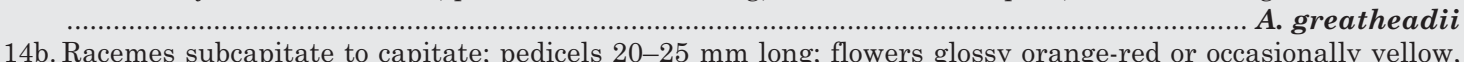

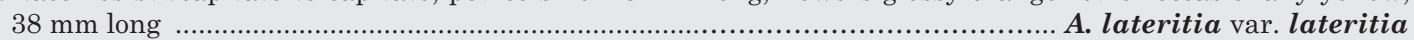

15a. Floral bracts very small, less than $5 \mathrm{~mm}$ long; pedicels more than four times longer than floral bracts

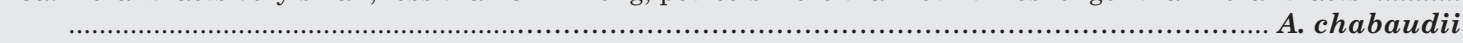

15b. Floral bracts larger, more than $6 \mathrm{~mm}$ long; pedicels twice as long as or equal to floral bracts 16

16a. Pedicels about twice as long as floral bracts

16b. Pedicles about equal in length to floral bracts

17a. Rosettes solitary, rarely suckering sparingly; leaves $50-80 \mathrm{~cm}$ long, dull green; racemes broadly capitate,

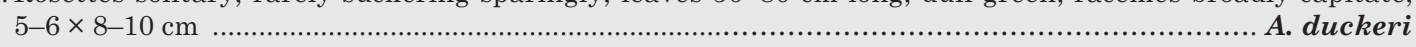

17b. Rosettes suckering to form small to large groups; leaves 20-35 cm long, grey to greyish green, sometimes with a reddish tinge; racemes broadly cylindric to subcapitate, $8-15 \times 6 \mathrm{~cm}$

18a. Racemes capitate or capitate-corymbose, 3-6 $57-9 \mathrm{~cm}$, dense; stamens and style slightly exserted

A. menyharthii subsp. menyharthii

18b. Racemes narrowly cylindrical-acuminate, 30-40 ×6 cm, dense to lax; stamens and style exserted to $2 \mathrm{~mm} . .$.

A. zebrina

Description: Much-branched shrub of 2-5 m high. Stems erect, with persistent dried leaves. Leaves densely rosulate at branch apices, spreading, becoming recurved, dull green to grey green, tinged reddish in dry conditions, without spots, lanceolate-attenuate, $40-60 \times 5-7 \mathrm{~cm}$; margin with firm, pale teeth, 3-5 mm long, 5-20 $\mathrm{mm}$ apart. Inflorescences $\pm 0.8 \mathrm{~m}$ high, erect, usually simple, occasionally with 1 or 2 short branches. Racemes conical to conical-cylindrical, 20-30 cm long, dense. Floral bracts 15-20 mm long. Pedicels 35$40 \mathrm{~mm}$ long. Flowers: perianth scarlet, often pink 

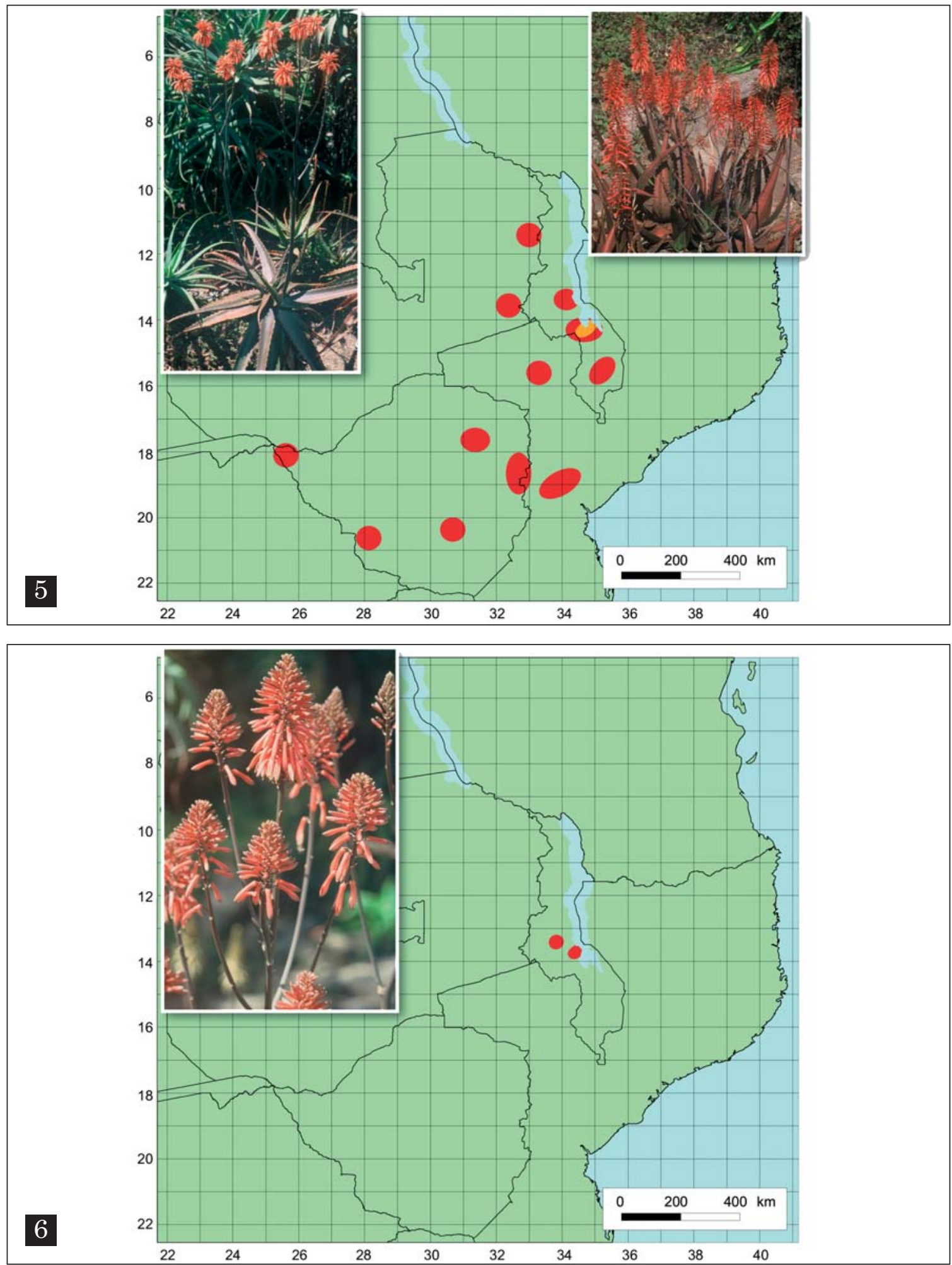

Figure 5. A. cameronii var. cameronii (red on map, left image) and $A$. cameronii var. dedzana (orange on map, right image). Figure 6. A. canis. 
turning yellow at anthesis, or occasionally yellow, paler towards mouth, green-tipped in bud, $\pm 40 \mathrm{~mm}$ long, $7 \mathrm{~mm}$ across ovary, narrowed above ovary, widening slightly towards mouth, cylindrictrigonous; outer segments free to base; stamens and style exserted to $5 \mathrm{~mm}$.

Flowering time: (end February) June to July.

Habitat: Rocky outcrops in mountainous areas of high summer rainfall.

Distinguishing characters: There is no easy set of distinguishing characters defining $A$. arborescens. This taxon can rather be identified by the following combination of characters: it is a much- branched shrub of up to $5 \mathrm{~m}$ high. The greyish green, somewhat sickle-shaped leaves with pale marginal teeth, are borne in dense rosettes at the branch apices. Inflorescences are usually simple with densely flowered, elongated-inverted coneshaped racemes. Floral bracts are large and pedicels are twice as long as the bracts. Flowers are cylindrical, with the outer segments free to the base.

Conservation status: Vulnerable; threatened in Malawi by habitat loss due to agriculture.

Distribution: The krantz aloe is very widely distributed in southeastern Africa and has the third

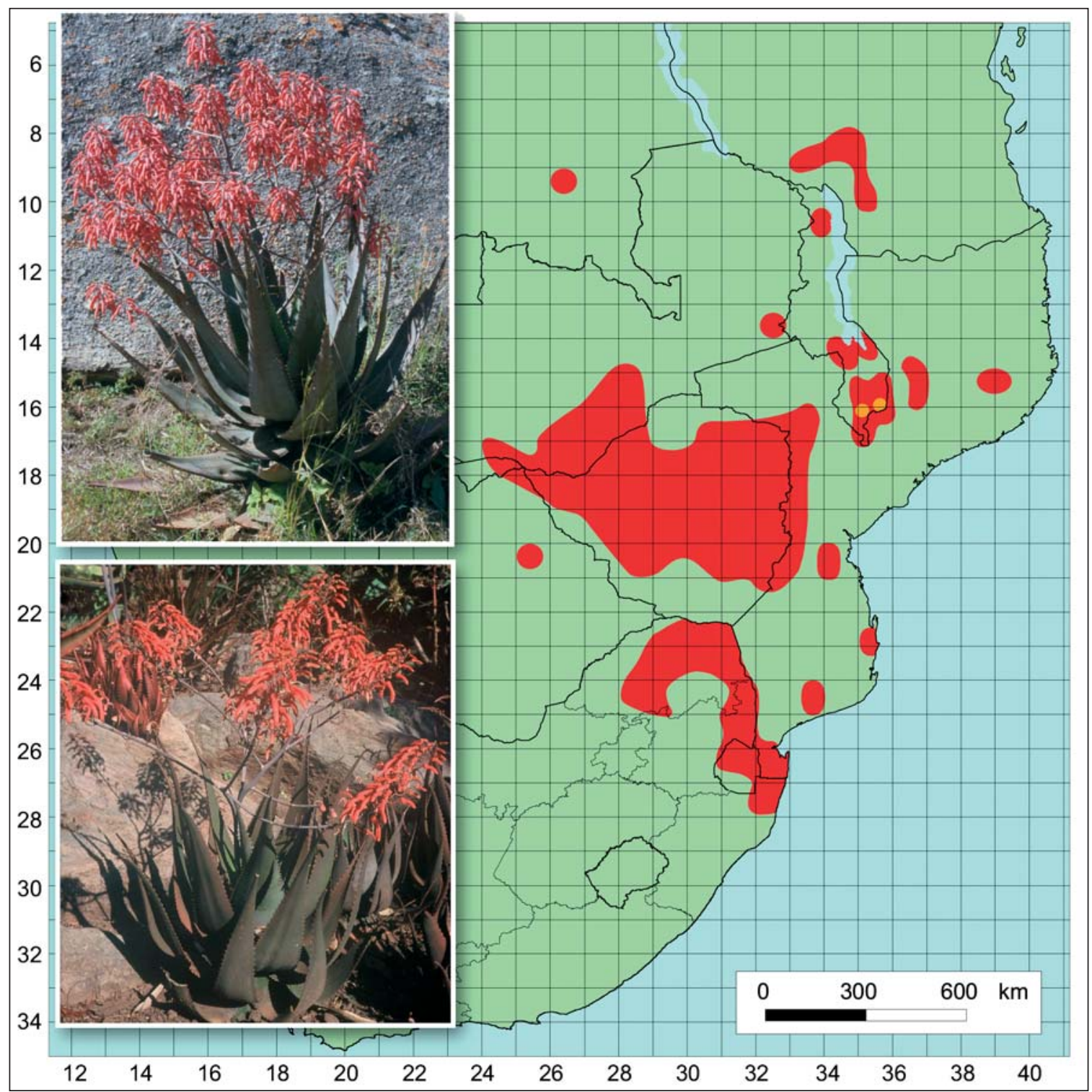

Figure 7. A. chabaudii var. chabaudii (red on map, top image) and A. chabaudii var. mlanjeana (orange on map, bottom image). 

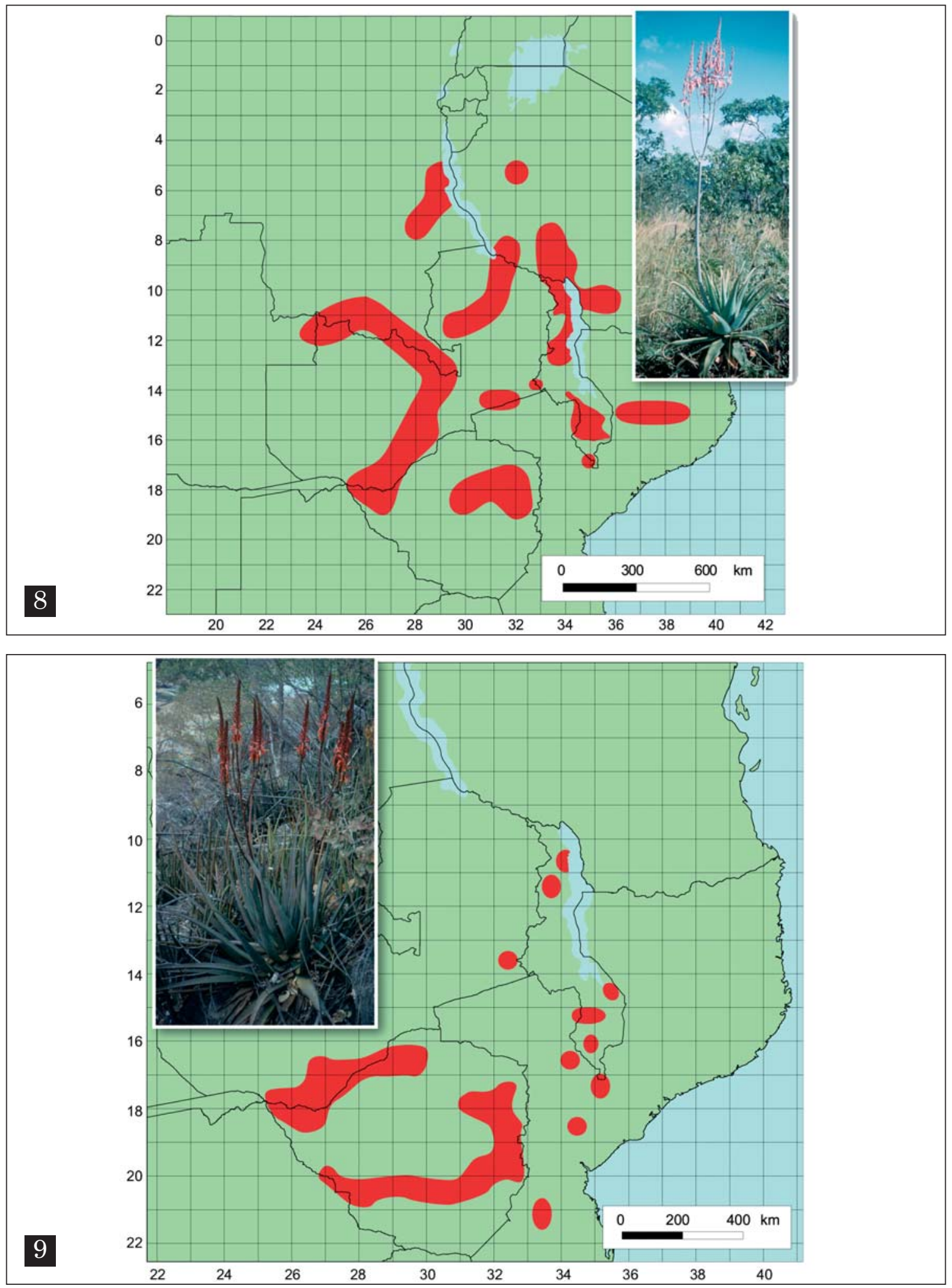

Figure 8. A. christianii. Figure 9. A. cryptopoda. 

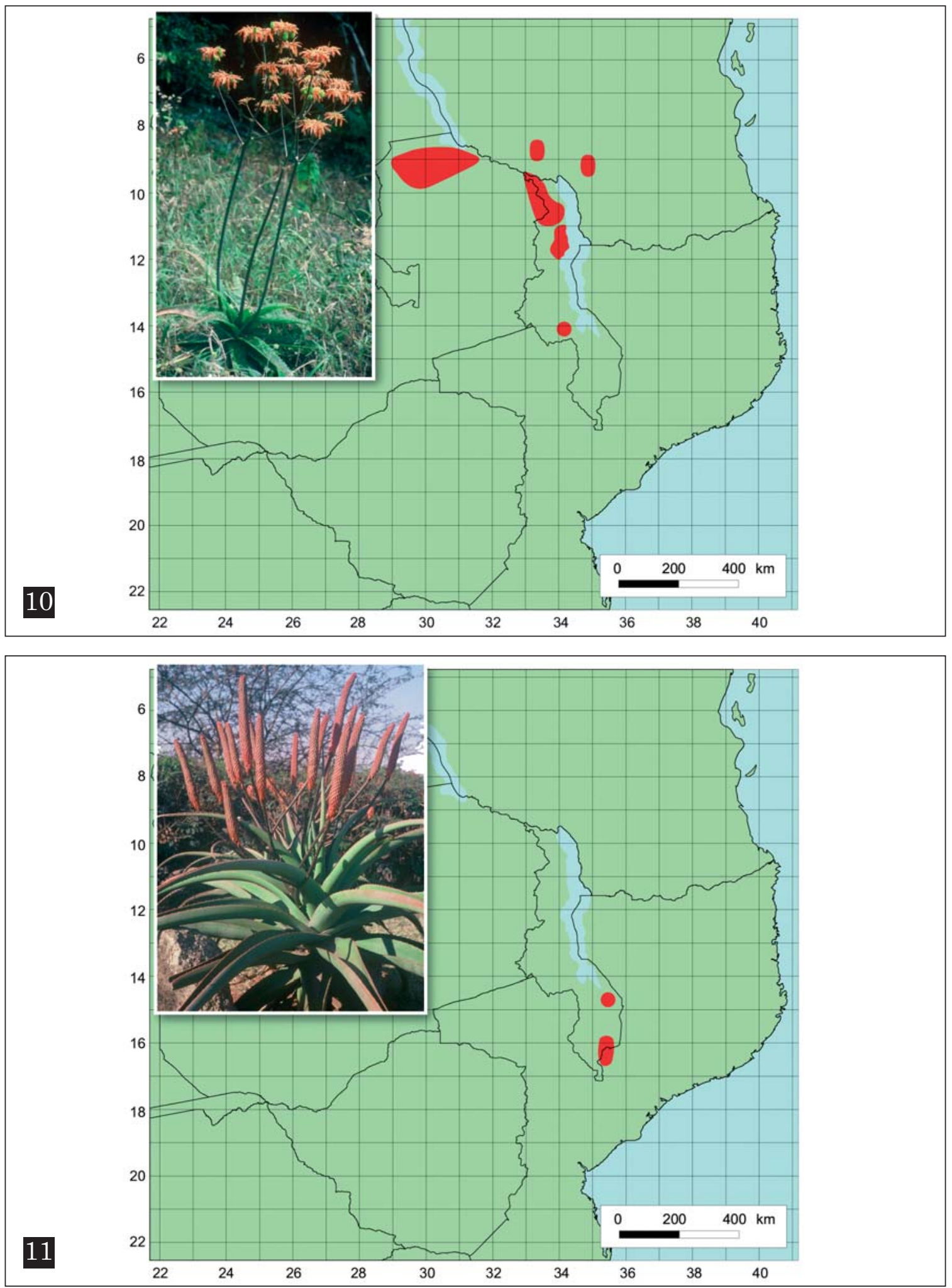

Figure 10. A. duckeri. Figure 11. A. excelsa var. breviflora. 
widest distribution range of all Aloe species (Smith et al., 2008). It occurs from the Cape Peninsula (where it has become naturalised), along the east coast of South Africa, from the Western Cape, through the Eastern Cape and KwaZulu-Natal and inland to Mpumalanga and Limpopo, just entering the eastern Free State, as well as further north to Mozambique and the eastern mountains of Zimbabwe and Malawi (Figure 2).

\section{${ }^{\mathrm{NE}}$ Aloe buchananii Baker}

Common names: maluwa (Chinyanja).

Description: Grass aloe. Acaulescent or with stem up to $0.2 \mathrm{~m}$ high, usually with persistent dried leaves; rosettes usually solitary, sometimes suckering to form dense clusters. Leaves distichous, sometimes becoming rosulate, erectly spreading, sometimes deflexed, grass-like, bright green, with few scattered elongate dull white spots near base, spots on lower surface more copious and usually tuberculate, linear, $\pm 60 \times 1.5-2 \mathrm{~cm}$, expanding to $4-6 \mathrm{~cm}$ wide at base; margin narrow, translucent, minutely denticulate with minute teeth, $0.5 \mathrm{~mm}$ long, 8-15 $\mathrm{mm}$ apart. Inflorescence $0.6-0.9 \mathrm{~m}$ high, simple. Raceme cylindric-acuminate, 15$20 \mathrm{~cm}$ long, dense. Floral bracts up to $25-30 \mathrm{~mm}$ long. Pedicels $35-40 \mathrm{~mm}$ long. Flowers: perianth salmon-pink to light coral-red, green-tipped, $\pm 30 \mathrm{~mm}$ long, $\pm 10-11 \mathrm{~mm}$ across ovary, narrowing towards the mouth, base tapering into pedicel, cylindric-trigonous; outer segments free almost to base; stamens not or scarcely exserted; style scarcely exserted.

Flowering time: February to June.

Habitat: Montane grassland and open Brachystegia woodland.

Distinguishing characters: A. buchananii can be distinguished from the other grass aloes in Malawi (A. myriacantha and $A$. nuttii) by its usually solitary rosettes of mostly distichous (rather than rosulate) leaves that are not distinctly keeled. Further distinguishing characters are the narrowly conical racemes with pedicels up to $40 \mathrm{~mm}$ long and lengthening to $50 \mathrm{~mm}$ in fruit. Flowers are light coral, taper to base and mouth, 25-30 mm long, $\pm 10 \mathrm{~mm}$ diameter across ovary, with a non-bilabiate mouth.

Conservation status: Endangered; threats include the small and fragmented population size in Malawi.

Distribution: Near-endemic to Malawi and Mozambique; only known from Malawi (the Shire Highlands, the Kirk Range and Mount Mulanje, occasionally found on some hills around Blantyre and Limbe) and adjacent areas of Mozambique (Figure 3).
Aloe bulbicaulis Christian

Common names: chinthembwe (Chewa/Tumbuka); khuzi (Ngoni); lichongwe (Yao).

Description: Acaulescent plants of up to $0.5 \mathrm{~m}$ high, with leaf bases enlarged below ground to form bulb-like swelling; rosettes solitary, erect. Leaves rosulate, deciduous, spreading, bright green, longitudinally striate, slightly fleshy, ovate-lanceolate, up to $50 \times 15 \mathrm{~cm}$; margin white, with densely crowded, fairly evenly-spaced, whitish teeth, $1 \mathrm{~mm}$ long, $1-5 \mathrm{~mm}$ apart. Inflorescence up to $0.6 \mathrm{~m}$ high, erect, 3-4-branched. Raceme cylindrical, 10-20 cm long, lax below, more dense above. Floral bracts 8-15 mm long. Pedicels $\pm 20 \mathrm{~mm}$ long. Flowers: perianth pale yellow to pinkish or brownish yellow with darker nerves, 35-40 $\mathrm{mm}$ long, 8-10 $\mathrm{mm}$ across ovary, slightly constricted above ovary, widening towards wide-open mouth, cylindrical; outer segments free for one-third (12-13 mm); stamens and style slightly exserted.

Flowering time: February to March

Habitat: Seasonally wet grassland in open woodland.

Distinguishing characters: A. bulbicaulis is easily distinguished by its underground bulb. Leaves of this aloe are up to $50 \mathrm{~cm}$ long and $15 \mathrm{~cm}$ wide in the middle, with densely crowded teeth of $1 \mathrm{~mm}$ long. The ovate-acuminate floral bracts are 8-15 mm long.

Conservation status: Vulnerable; threatened in Malawi by its small population size in the country.

Distribution: Widespread in eastern Angola (Moxico), southeastern Democratic Republic of the Congo (Katanga), northern Malawi, northwestern Mozambique, southwestern Tanzania and northern Zambia (Figure 4).

General notes: Reynolds (1966) considered A. bulbicaulis to be conspecific with $A$. buettneri together with A. paedogona. Carter (1994) stated that the three taxa are morphologically clearly distinct and also separated geographically and therefore does not agree with Reynold's opinion that the three taxa are conspecific.

Aloe cameronii Hemsl.

Inflorescence 2-3-branched; racemes 7-15 $\times$ 3-7 $\mathrm{cm}$ wide.

A. cameronii var. cameronii

Inflorescence usually simple, only sometimes branched; racemes $20-30 \times 5-6 \mathrm{~cm}$ wide ........ ${ }^{\mathrm{E}}$ A. cameronii var. dedzana Reynolds

Common names: chinthembwe (Chewal Tumbuka); khuzi (Ngoni); lichongwe (Yao).

Description: Erect or spreading to sprawling, branched shrub of up to $1.5 \mathrm{~m}$ high. Stem up to 
$1.5 \mathrm{~m}$ high, ascending, with persistent dried leaves. Leaves laxly rosulate, erectly spreading, green in rainy season, mostly turning bright copper-red in dry season, usually without spots, occasionally with few whitish spots on young leaves, rarely slightly lineate, lanceolate-attenuate, $25-50 \times 3-7 \mathrm{~cm}$ (var. cameronii) or $\pm 45 \times 5-$ $7 \mathrm{~cm}$ (var. dedzana); margin with pale brown, pungent teeth, 2-3 $\mathrm{mm}$ long, $10-15 \mathrm{~mm}$ apart. Inflorescence $0.6-0.9 \mathrm{~m}$ (var. cameronii) or $\pm 1 \mathrm{~m}$ (var. dedzana) high, erect, 2-3-branched (var. cameronii) or simple and only sometimes branched (var. dedzana). Raceme cylindric, slightly acuminate, $7-15 \mathrm{~cm}$ long, subdense (var. cameronii) or 20-30 cm long, rather lax (var. dedzana). Floral bracts 1-3 mm (var. cameronii) or $\pm 2 \mathrm{~mm}$ long (var. dedzana). Pedicels $3-8 \mathrm{~mm}$ (var. cameronii) or $\pm 5 \mathrm{~mm}$ long (var. dedzana). Flowers: perianth bright deep-scarlet, rarely yellow, $\pm 45 \mathrm{~mm}$ long, 4-7 $\mathrm{mm}$ across ovary, slightly widening towards mouth, slightly constricted at mouth, slenderly cylindric-curved, sometimes slightly clavate; outer segments free for 12 $15 \mathrm{~mm}$; stamens and style exserted to $\pm 5 \mathrm{~mm}$.

Flowering time: April to August (var. cameronii) and March to June (var. dedzana).

Habitat: On bare granite outcrops and amongst boulders, in exposed situations with grass tussocks or light miombo woodland (var. cameronii). Among rocks in open woodland (var. dedzana).

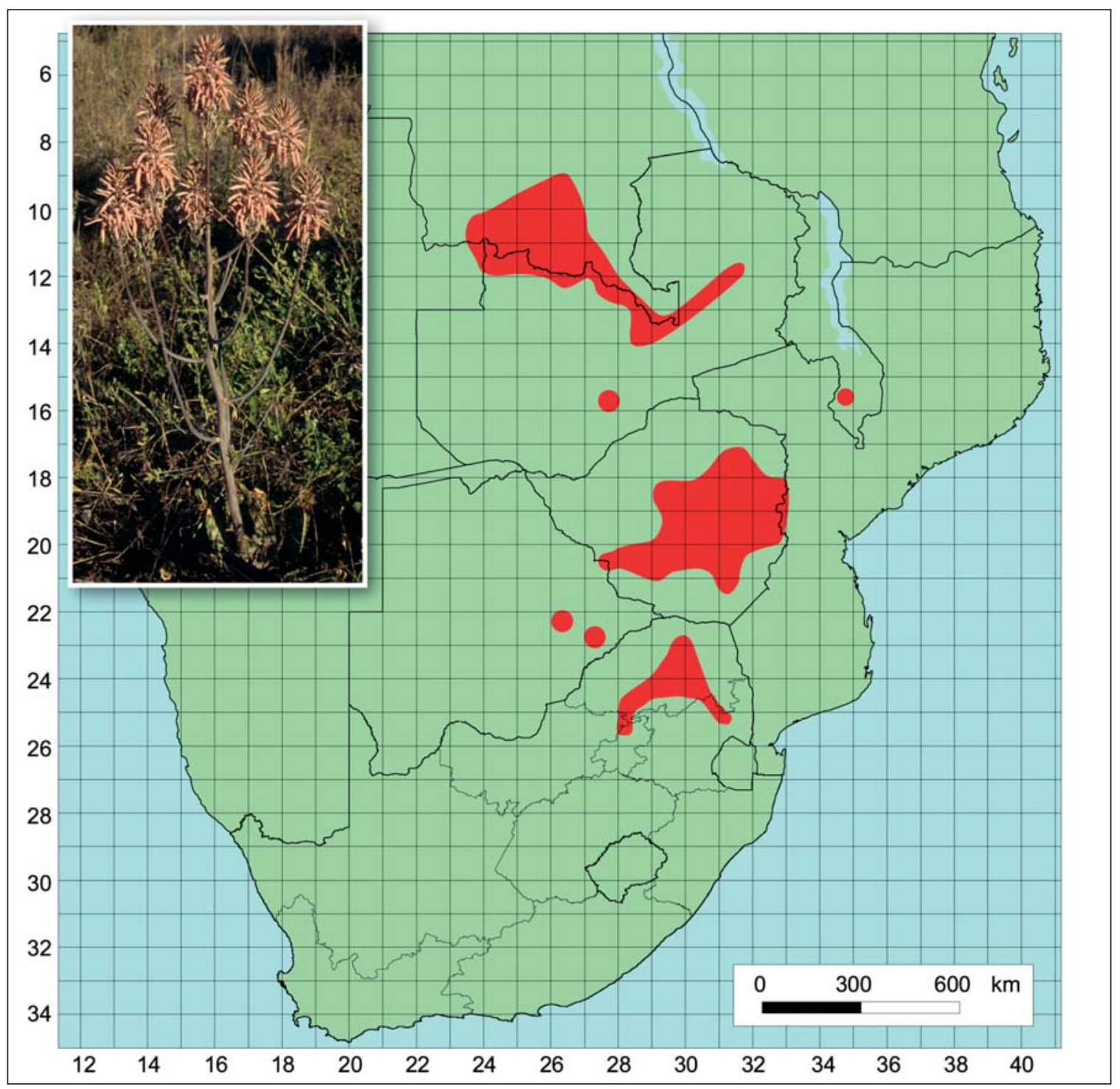

Figure 12. A. greatheadii. 
Distinguishing characters: These erect to spreading shrubs can be easily distinguished by their leaves that turn a coppery red in the dry season and the $\pm 45 \mathrm{~mm}$ long flowers that are mostly bright red (only rarely yellow), slender and slightly curved, with stamens and style exserted up to $5 \mathrm{~mm}$. Inflorescences of $A$. cameronii var. cameronii are dichotomously 2-3-branched, with racemes $7-15 \times 3-7 \mathrm{~cm}$, while those of $A$. cameronii var. dedzana are usually simple and only sometimes branched, with racemes $20-30 \times \pm 5 \mathrm{~cm}$.

Conservation status: $A$. cameronii var. cameronii: Vulnerable; threatened in Malawi by habitat loss and the small number of populations. A. cameronii var. dedzana: Critically Endangered; threatened by habitat loss due to agriculture and forestry exploitation.

Distribution: A. cameronii var. cameronii occurs rather widespread in eastern Zambia, eastern and southern Malawi, western and central Mozambique and eastern Zimbabwe. A. cameronii var. dedzana is endemic to Malawi and only known from Dedza Mountain and at the foot of this mountain in Monkey Bay (Figure 5). The third variety of this aloe, $A$. cameronii var. bondana Reynolds is not present in Malawi and known only from the Nyanga district in Zimbabwe.

General notes: A. cameronii var. dedzana was thought to be extinct in the wild, but there is a small population in Chongoni Forest reserve (next to Dedza Mountain).

\section{${ }^{\mathrm{E}}$ Aloe canis S.Lane}

Common names: chinthembwe (Chewa/ Tumbuka); khuzi (Ngoni); lichongwe (Yao).

Description: Solitary, caulescent, mostly unbranched plants. Stem up to $2.5 \mathrm{~m}$ high, erect, with persistent dried leaves. Leaves densely rosulate, erectly spreading, dark green above and olive green below in rainy season, becoming reddish in dry season, with scattered white spots near base, white spots along midrib of lower surface, lanceolate, up to $45 \times 5-7 \mathrm{~cm}$; margins with pungent brown teeth, $2-3 \mathrm{~mm}$ long, $15-23 \mathrm{~mm}$ apart. Inflorescence 1.0-1.5 m high, erect, 4-5branched. Racemes shortly cylindric-acuminate, $14 \mathrm{~cm}$ long, dense. Floral bracts $3-4 \mathrm{~mm}$ long. Pedicels $10-11 \mathrm{~mm}$. Flowers: perianth pinkish scarlet, $34 \mathrm{~mm}$ long, $5 \mathrm{~mm}$ across ovary, narrowing above ovary, widening towards mouth, constricted at mouth, cylindrical; outer segments free for $10 \mathrm{~mm}$; stamens not or scarcely exserted; style exserted to $4 \mathrm{~mm}$.

Flowering time: June to August.

Habitat: Amongst rocks in light forest.

Distinguishing characters: A. canis is easily distinguished from other tall, single-stemmed aloes in Malawi (A. excelsa var. breviflora and A. mawii) by its branched inflorescence (with 4 to 5 branches) with erect racemes and pinkish scarlet flowers that are not secund. The leaves are dark green above and olive green below in the rainy season, becoming reddish in the dry season, and with a few scattered elliptical spots at the base on both surfaces and along the midrib of the lower surface. The stem of $A$. canis is mostly simple and up to $2.5 \mathrm{~m}$ high.

Conservation status: Critically Endangered; this aloe is probably extinct in the wild. It is known from only one location. Further investigation into this taxon and searching for it in the wild is required, as the previous search for it was not exhaustive.

Distribution: Endemic to Malawi; only known from the Senga Hills in the Salima District (Figure 6).

General notes: Has not been relocated in the wild.

\section{Aloe chabaudii Schönland}

Leaves up to $60 \mathrm{~cm}$ long; inflorescence usually erect, $0.6-1.5 \mathrm{~m}$ long; racemes $4-15 \mathrm{~cm}$ long, erect; flowers pale brick red or bright coralpink, sometimes orange to yellow, not secund

\section{A. chabaudii var. chabaudii}

Leaves 30-40 cm long; inflorescence oblique, 0.4$0.5 \mathrm{~m}$ long; racemes $16-18 \mathrm{~cm}$ long, \pm horizontal; flowers deep coral, pink, orange or yellow, subsecund.

... ${ }^{\mathrm{E}}$ A. chabaudii var. mlanjeana Christian Common names: grey aloe; khonje was fisi/mbuzi (Chichewa); madaka, ngosiya, chisongwe (Chiyao); chinthembwe (Chewa/Tumbuka); khuzi (Ngoni); lichongwe (Yao); nemba (uncertain).

Description: Acaulescent plants or with stem very short, suckering or dividing to form dense groups; rosettes up to $0.5 \mathrm{~m}$ high. Leaves rosulate, erect or spreading, slightly recurved towards apex, dull grey-green to glaucous green, sometimes with reddish tinge (var. chabaudii) or dull green to greyish green, turning dull brick red in upper part of upper surface during dry season (var. mlanjeana), obscurely lineate, usually without spots, sometimes with few small confluent, H-shaped, scattered spots, ovate-lanceolate, acuminate, up to 60 $\times 8-15 \mathrm{~cm}$ (var. chabaudii) or 30-40 $\times \pm 10 \mathrm{~cm}$ (var. mlanjeana); margin cartilaginous, narrow, greyish (var. chabaudii) or white (var. mlanjeana), with small, pale to brownish teeth, 1-3 mm long, 5-10 $\mathrm{mm}$ apart (var. chabaudii) or 10-15 mm apart (var. mlanjeana). Inflorescence 0.6-1.5 m (var. chabaudii) or 0.4-0.5 m (var. mlanjeana) high, erect (var. chabaudii) or oblique (var. chabaudii and var. mlanjeana), 6-12-branched (8-12-branched in var. mlanjeana) 
from below middle, lower branches rebranching. Racemes broadly cylindric, slightly acuminate, occasionally sub-capitate, $4-15 \mathrm{~cm}$ long, sublax (var. chabaudii) or 16-18 cm long, horizontal, dense to lax with flowers subsecund when open (var. mlanjeana). Floral bracts $3-6 \mathrm{~mm}$ long. Pedicels up to 20-25 mm (var. chabaudii) or 18-20 mm long (var. mlanjeana). Flowers: perianth pale brick red or bright coral-pink, sometimes orange to yellow, paler at mouth, 35-40 mm (var. chabaudii) or 26$38 \mathrm{~mm}$ (var. mlanjeana) long, 7-9 $\mathrm{mm}$ across ovary, narrowed above ovary, widening towards mouth, cylindric-trigonous, decurved; outer segments free for $\pm 8 \mathrm{~mm}$ (var. chabaudii) or for $\pm 12 \mathrm{~mm}$ (var. mlanjeana); stamens and style exserted to $2 \mathrm{~mm}$.
Flowering time: April to August (var. chabaudii) or May to July (var. mlanjeana).

Habitat: Usually on bare rock on granite domes, at foot of granite whalebacks and outcrops, or in shallow soil pockets. Frost-sensitive. A. chabaudii var. mlanjeana grows in shallow soil in rocky areas.

Distinguishing characters: A. chabaudii is an extremely variable taxon. It is best distinguished from other acaulescent or very short stemmed aloes in Malawi by the combination of its suckering rosettes of erectly spreading, obscurely lineate, usually unspotted, glaucous green leaves with pale margins and the much-branched (with up to 12 branches) inflorescence with broadly cylindric to capitates racemes, as well as the short

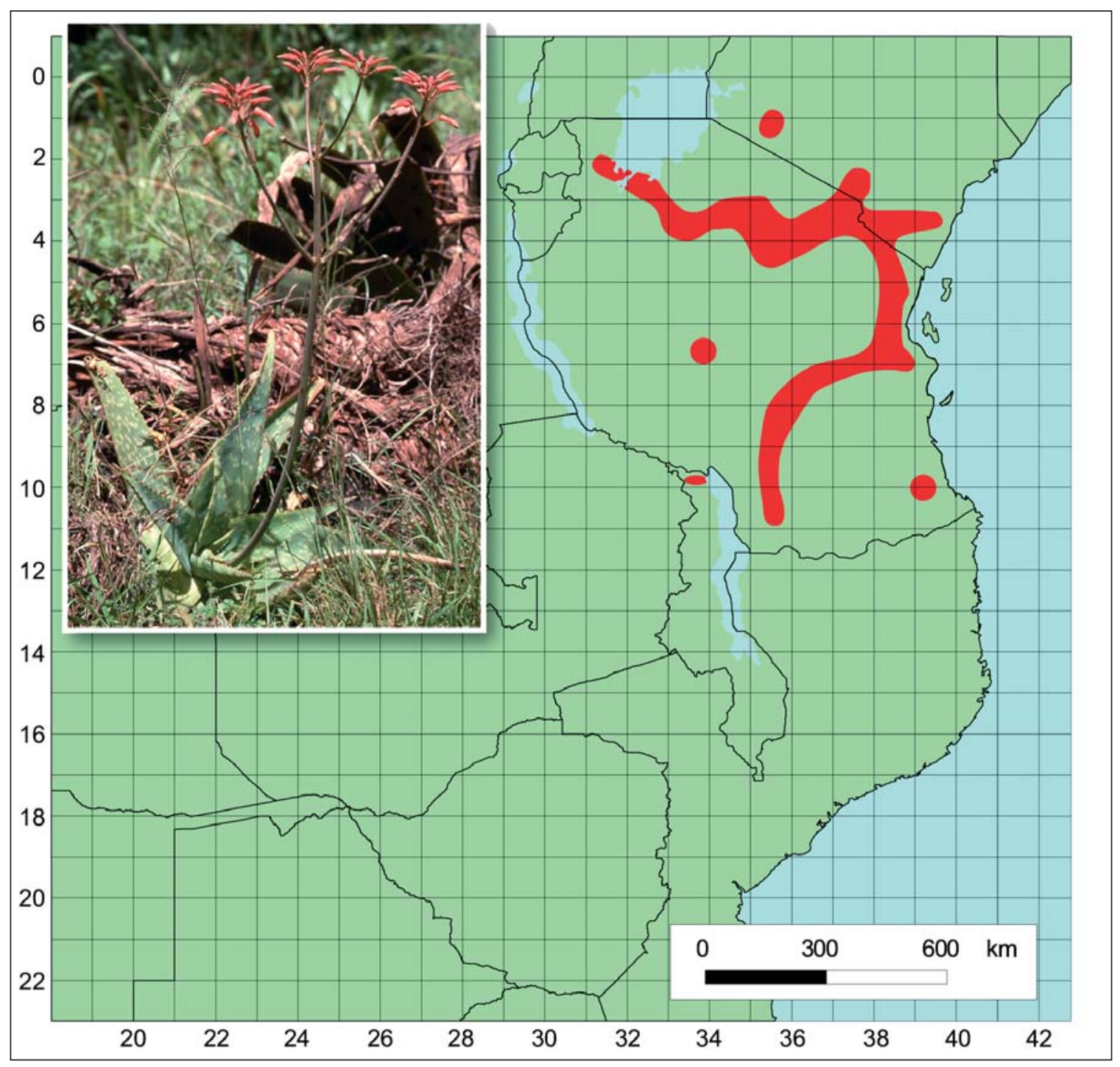

Figure 13. A. lateritia var. lateritia. 

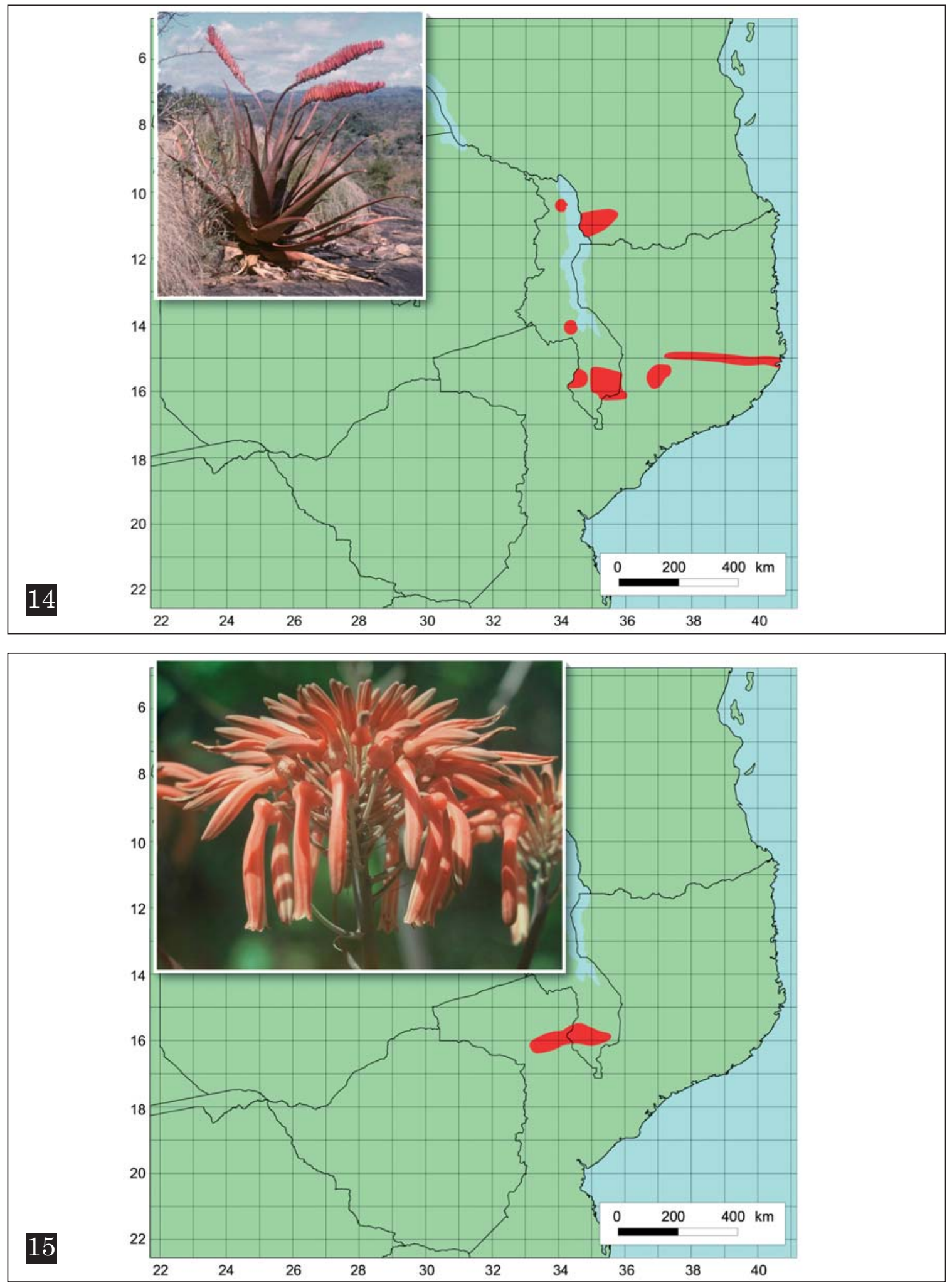

Figure 14. A. mawii. Figure 15. A. menyharthii subsp. menyharthii. 
floral bracts (up to $6 \mathrm{~mm}$ ) and much longer pedicels (18-25 $\mathrm{mm})$. The two varieties can be distinguished as follows: A. chabaudii var. chabaudii has greyish green to dark olive-green leaves with small rather closely-spaced teeth (5$10 \mathrm{~mm}$ apart) and an erect to oblique inflorescence (up to $1.5 \mathrm{~m}$ high), with spreading branches and erect racemes of mostly reddish flowers and oblique to almost horizontal pedicels. A. chabaudii var. mlanjeana has bright green leaves, which turn dull brick red in the upper part of the upper surface during the dry season, with a narrow, horny white line on the margin and more widely spaced teeth (10-15 $\mathrm{mm}$ apart). It has a short inflorescence (0.4-0.5 m high) that always rises at an oblique angle or changes direction at each node, with pronouncedly spreading branches and horizontal racemes of upwards turning, deep coral, pink, orange or yellow flowers that become subsecund.

Conservation status: A. chabaudii var. chabaudii: Critically Endangered; threats in Malawi include habitat degradation and over-collecting. A. chabaudii var. mlanjeana: Critically Endangered; threatened by habitat loss and overexploitation for medicinal use.

Distribution: The centre of distribution of A. chabaudii var. chabaudii is in Zimbabwe. The distribution range of this aloe also extends north to Zambia and Malawi and southwestern Tanzania, west into eastern Botswana, east to Mozambique and south to South Africa (Limpopo, Mpumalanga and northern KwaZulu-Natal provinces), as well as Swaziland. A. chabaudii var. mlanjeana is endemic to Malawi and is confined to the Mulanje Mountain and hills in Thyolo and Mulanje District (Figure 7).

\section{Aloe christianii Reynolds}

Common names: chinthembwe (Chewa/Tumbuka); lichingwe, nsenjere (Chinyanja); chizimamuliro (Ngoni); iwani, khuzi, chizime (uncertain). Description: Acaulescent plants; rosettes usually solitary, up to $1 \mathrm{~m}$ across, or in small groups, rarely suckering. Stem develops in older plants, up to $1 \mathrm{~m}$ long, erect or decumbent, with persistent dried leaves. Leaves densely rosulate, erectly spreading, dull green above, dull bluish green below, tinged pinkish in dry conditions, unspotted but often obscurely lineate, lanceolate-attenuate, 30-65 × 10-12 cm; margin pale green, with pungent, pinkish to pale brown, brown-tipped teeth, 2-5 $\mathrm{mm}$ long, 10-20 $\mathrm{mm}$ apart. Inflorescence 2-3 m high, erect, compactly 6-10-branched from above middle, lower branches sometimes rebranched. Raceme cylindric-acuminate, $15-30 \mathrm{~cm}$ long, terminal raceme the longest, subdense.
Floral bracts 8-18 $\mathrm{mm}$ long. Pedicels $8-20 \mathrm{~mm}$ long. Flowers: perianth bright coral-pink with a bloom and obscure nerves, lighter and brownish at tips, 35-45 $\mathrm{mm}$ long, $8-10 \mathrm{~mm}$ across ovary, not narrowed above ovary, cylindric-trigonous, straight; outer segments free for $15 \mathrm{~mm}$; stamens exserted 3-4 mm; style exserted 4-5 mm.

Flowering time: March to July.

Habitat: Usually in shade in woodland, sometimes in tall grassland, never on rocks.

Distinguishing characters: A. christianii can be easily distinguished by its large rosette of erectly spreading, unspotted, dull green leaves that are tinged pinkish in dry conditions, and its tall (2$3 \mathrm{~m}$ high), erect, branched inflorescence with long $(15-30 \mathrm{~cm})$, bright coral-pink, subdense racemes of thick, fleshy, cylindric-trigonous flowers, with the outer perianth segments free for only $15 \mathrm{~mm}$. Conservation status: Least concern. This aloe still occurs widely in Malawi despite severe habitat loss in certain areas.

Distribution: Widespread in eastern Angola (Moxico), southern and eastern Democratic Republic of the Congo, Malawi, northern Mozambique, eastern Tanzania, Zambia and northern Zimbabwe (Figure 8).

\section{Aloe cryptopoda Baker}

Common names: spire aloe; ngafane (seKone); mdyang'oma (Ngoni); gave wamtchanga (Sena).

Description: Acaulescent plants or with stem very short, decumbent; rosettes usually solitary, up to $0.12 \mathrm{~m}$ diameter, or sometimes suckering to form dense groups. Leaves densely rosulate, erect and slightly curving inwards, dull dark greyish green, tinged with purple in dry conditions, without spots, lanceolate-attenuate, up to $120 \times 7-12 \mathrm{~cm}$; margin thin, red, with pungent, pinkish teeth, 1-3 $\mathrm{mm}$ long, 2-10 $\mathrm{mm}$ apart. Inflorescence 1.00-1.75 m high, erect, 1-4-branched from middle or below, sometimes rebranched. Racemes narrowly cylindric-acuminate, 20-45 cm long, dense; buds covered by imbricate bracts. Floral bracts $10-15 \mathrm{~mm}$ long. Pedicel $15-20 \mathrm{~mm}$ long. Flowers: perianth bright scarlet or orange-scarlet, paler to yellowish-tipped at maturity, greentipped in bud, 28-35 $\mathrm{mm}$ long, 8-9 $\mathrm{mm}$ across ovary, not narrowed above ovary, cylindric-trigonous; outer segments free to base; stamens exserted $2-3 \mathrm{~mm}$; style exserted to $5 \mathrm{~mm}$.

Flowering time: June to August or February to March.

Habitat: Open savanna woodland, sometimes on rocks, in summer rainfall areas with light to no frost in winter.

Distinguishing characters: A. cryptopoda can be distinguished by its usually solitary rosettes of 
long (up to $120 \mathrm{~cm}$ ), ascending, unspotted, green leaves with thin red margins and its erect (1.00$1.75 \mathrm{~m}$ high), narrow, branched inflorescences with very long (up to $45 \mathrm{~cm}$ ), scarlet or scarlet and yellow, dense racemes of cylindric-trigonous flowers, with the outer perianth segments free to the base. A further distinguishing character is the flower buds that are covered by the imbricate floral bracts, which also clasp and hide the pedicels of mature flowers.

Conservation status: Vulnerable; threatened in Malawi by habitat loss resulting in small and fragmented subpopulations in the country.

Distribution: Widespread in southern and eastern Zambia, Malawi, western and central Mozambique and Zimbabwe (Figure 9).

General notes: Plants attributed to A. cryptopoda north of Mpatamanga Gorge are notably different from the form further south in Malawi and in the rest of the distribution range of this aloe. The northern form has inflorescences that bear no more than two upright branches. It is also still uncertain whether plants ascribed to $A$. pienaarii Pole Evans and A. wickensii Pole Evans (from Botswana, the northern provinces of South Africa, Swaziland and southern Mozambique), are to be treated as separate taxa or conspecific with A. cryptopoda. For the purpose of this treatment the latter taxa were excluded from the concept of A. cryptopoda. This is also supported by a view that $A$. pienaarii and $A$. wickensii are perhaps closer to $A$. lutescens Groenew., with $A$. pienaarii seen as an intermediate between $A$. cryptopoda and the two southern taxa (Reynolds, 1950).

\section{Aloe duckeri Christian}

Common names: chinthembwe (Chewa/Tumbuka); khuzi (Ngoni); lichongwe (Yao).

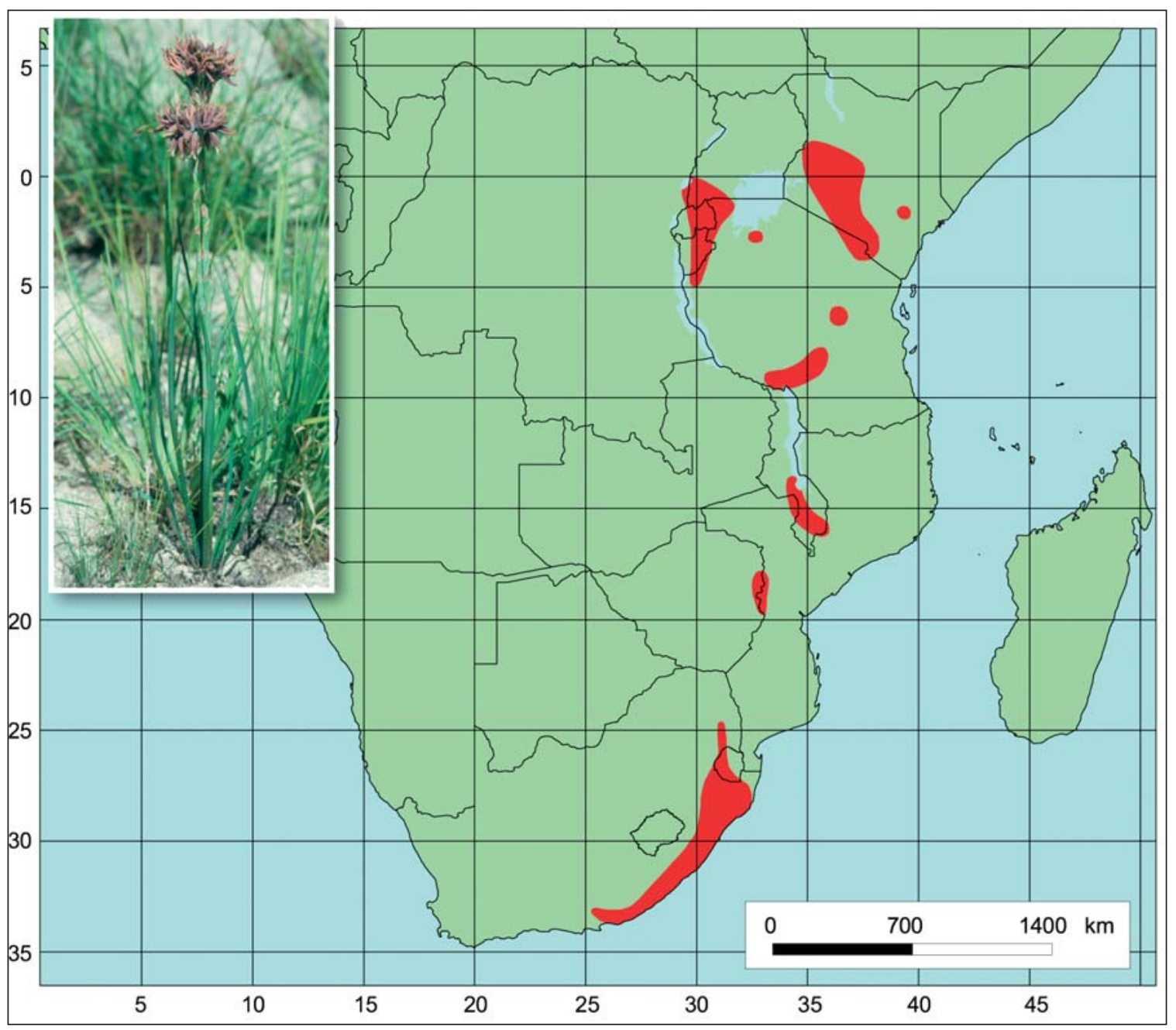

Figure 16. A. myriacantha. 
Description: Acaulescent plants or with stem short, up to $1 \mathrm{~m}$ high; rosettes solitary, up to $1 \mathrm{~m}$ diameter, rarely suckering sparsely. Leaves rosulate, spreading to slightly recurved, dull green, upper surface somewhat obscurely lined, without spots or with few scattered whitish elongated spots, lower surface strongly to obscurely lined, lanceolate-attenuate, 50-80 × 8-12 cm; margin with pungent, red-brown teeth, $4-5 \mathrm{~mm}$ long, 10-20 $\mathrm{mm}$ apart. Inflorescence 1-2 $\mathrm{m}$ high, erect, 6-10-branched from above the middle, lowest branches sometimes rebranched. Racemes broadly capitate, 5-6 $\mathrm{cm}$ long, dense. Floral bracts $15-20 \mathrm{~mm}$ long. Pedicels $\pm 30 \mathrm{~mm}$ long. Flowers: perianth orange-red to coral-pink at maturity, green-tipped in bud, 23-45 $\mathrm{mm}$ long, $\pm 10 \mathrm{~mm}$ across ovary, abruptly narrowed above ovary to form globose basal swelling, widening towards slightly upturned mouth, laterally compressed, slightly decurved; outer segments free for
12-13 mm; stamens exserted $2-3 \mathrm{~mm}$; style slightly exserted.

Flowering time: April to August.

Habitat: Montane grassland and grass in high rainfall open miombo woodland.

Distinguishing characters: $A$. duckeri is the only maculate aloe in Malawi that has a stout upright stem when mature. It can also be distinguished from other maculate aloes in Malawi (A. greatheadii, A. lateritia var. lateritia, A. menyharthii subsp. menyharthii and A. zebrina) by the following combination of characters: the dull green leaves that are thin and less rigid than many other spotted aloes with strongly to obscurely lined lower surface; broadly capitate racemes with bright green buds and flowers that are orange-red to coral-pink with a slightly upturned mouth; pedicels $\pm 30 \mathrm{~mm}$ long. A further distinguishing character is the upper lateral racemes that are often level with or slightly above the terminal one,

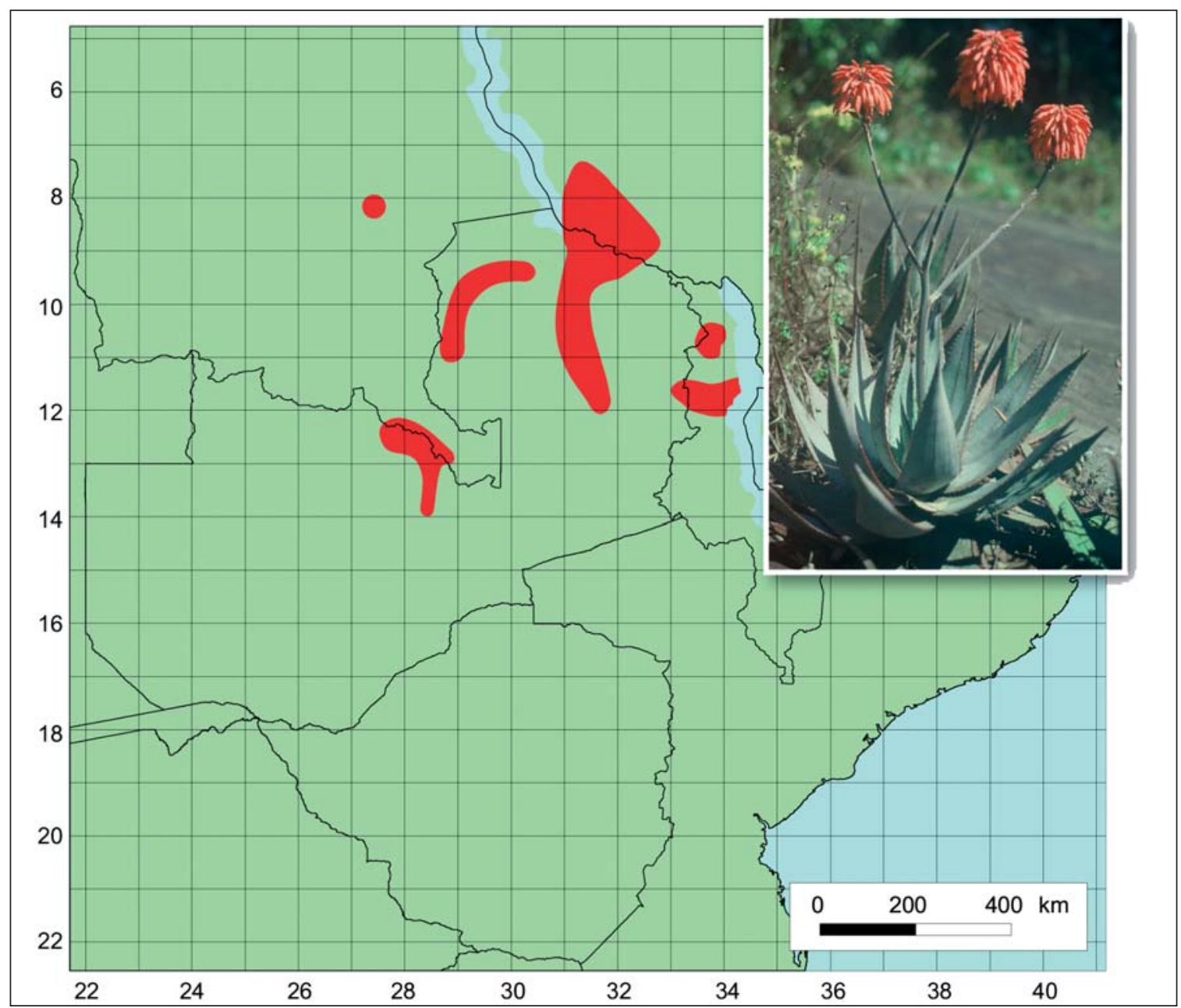

Figure 17. A. mzimbana. 
whereas in other maculates in Malawi (except for A. menyharthii subsp. menyharthii) the terminal raceme is usually the longest.

Conservation status: Vulnerable; threatened in Malawi by habitat loss, medicinal use and its small distribution range.

Distribution: Occurs in northern Malawi, northeastern Zambia and southwestern Tanzania (Figure 10).

\section{${ }^{\mathrm{NE}}$ Aloe excelsa A.Berger var. breviflora L.C.Leach}

Description: Single-stemmed tree aloe of up to $5 \mathrm{~m}$ high. Stem 2-4 m high, erect, with persistent dried leaves. Leaves densely rosulate, suberectly spreading to recurved, dull green, often tinged reddish, without spots, usually without prickles, lanceolate-attenuate, up to $135 \times$ up to $13 \mathrm{~cm}$; margin red, with pungent, reddish brown teeth, 3-4 mm long, 15-30 mm apart. Inflorescence 0.8$1.0 \mathrm{~m}$ high, erect, up to 15-branched from below middle, lower branches rebranched. Racemes cylindrical-conical, 20-30 cm long, dense. Floral bracts $3 \mathrm{~mm}$ long. Pedicels $\pm 1 \mathrm{~mm}$ long. Flowers: perianth bright reddish to reddish orange, $\pm 20 \mathrm{~mm}$ long, $4 \mathrm{~mm}$ across ovary, widening towards middle, narrowing slightly towards wideopen mouth, cylindric, slightly ventricose; outer segments free for $\pm 20 \mathrm{~mm}$; stamens and style exserted to $10 \mathrm{~mm}$.

Flowering time: June to October.

Habitat: Fire protected habitats, like rocky slopes with deciduous woodland.

Distinguishing characters: A. excelsa var. breviflora is easily distinguished from other tall, single-stemmed aloes in Malawi (A. canis and A. mawii) by its much-branched inflorescence (with up to 15 branches and lower branches often rebranching; the inflorescence of $A$. canis can have up to 5 branches) with most racemes oblique to erect, and red to reddish orange flowers that are not secund. The leaves are dull green, often tinged reddish and without spots, and much larger than those of either A. canis or A. mawii. The stem of $A$. excelsa var. breviflora is simple and can be up to $5 \mathrm{~m}$ high.

Conservation status: Critically Endangered; threatened by habitat loss and its small population size.

Distribution: Near-endemic to Malawi and Mozambique; only known from the lower reaches of the Ruo River on the Malawi-Mozambique border (Figure 11). A. excelsa var. excelsa is not present in Malawi, but is widespread throughout Zimbabwe, and scattered in central Zambia, northern Botswana and northeastern South Africa.
'Aloe greatheadii Schönland

Common names: Greathead's spotted-leaf aloe; kizima-bupia (Kitabwa); itembushia (uncertain).

Description: Acaulescent plants or with stem short, up to $0.3 \mathrm{~m}$ high, with persistent dried leaves; rosettes solitary or suckering to form groups. Leaves densely rosulate, spreading, upper surface reddish brown or somewhat glossy dark green, with numerous irregularly scattered elongated whitish spots, sometimes in broken transverse bands, lower surface pale greyish green, mostly without spots, lineate with dark green interrupted longitudinal lines, broadly lanceolate, $20-40 \times 6-12 \mathrm{~cm}$, usually with $\pm 10 \mathrm{~cm}$ of dried twisted apex; margin often brownish, with pungent, reddish brown teeth, 3-6 mm long, 10$15 \mathrm{~mm}$ apart. Inflorescence up to $1.75 \mathrm{~m}$ high, erect, 3-7-branched from above middle, lowest branches sometimes rebranched. Racemes cylindric-acuminate, 8-20 cm long, rather dense. Floral bracts $10-15 \mathrm{~mm}$ long. Pedicels $12-18 \mathrm{~mm}$ long. Flowers: perianth dull flesh-pink, white striped, 25-32 $\mathrm{mm}$ long, 7-8 $\mathrm{mm}$ across ovary, constricted above ovary to form globose basal swelling, enlarging towards mouth, decurved, cylindric-trigonous; outer segments free for $9 \mathrm{~mm}$; stamens exserted to $1 \mathrm{~mm}$; style exserted to $2 \mathrm{~mm}$. Flowering time: May to July.

Habitat: Rocky outcrops in mid to high altitude grassland, also on termitaria.

Distinguishing characters: A. greatheadii is an extremely variable species and is difficult to identify. It can be distinguished from other maculate aloes in Malawi (A. duckeri, A. lateritia var. lateritia, A. menyharthii subsp. menyharthii and A. zebrina) by the following combination of characters: the reddish brown or somewhat glossy dark green leaves with often brownish margin and paler, usually unspotted lower surface; cylindric-acuminate racemes with buds and open flowers that are dull flesh-pink and white striped to the base or almost to the base; pedicels $12-18 \mathrm{~mm}$ long.

Conservation status: Critically Endangered; threatened by habitat loss resulting in small and fragmented subpopulations in Malawi.

Distribution: It is known with certainty only from eastern Botswana and Zimbabwe, where it is widespread and crosses the border into Mozambique. Populations in northern South Africa (Limpopo, Mpumalanga, Gauteng) (Glen \& Hardy, 2000) could possibly be referred to a mixture of $A$. greatheadii with A. davyana Schönland (Carter, 2001). Localities cited for the southern Democratic Republic of the Congo and Zambia (Reynolds, 1966) are more likely A. zebrina Baker (Carter, 2001). In Malawi it is possibly 
represented by plants from Chikhala and Lirangwe (Lane, 2004), but actual occurrence of this aloe in Malawi is uncertain (Figure 12).

\section{Aloe lateritia Engl. var. lateritia}

Common names: ngaka (Bashu); igikakarubamba (Kignaruanda); ngarare (Kirundi); kidata (Kiviru). Description: Acaulescent plants; rosettes solitary, sometimes suckering to form small groups. Leaves densely rosulate, suberect to spreading, dull or glossy bright green to brownish green, usually copiously spotted with obscure, rather large, elongated blotches, sometimes irregularly scattered, sometimes confluent and H-shaped, lower surface paler green with fewer and more obscure, irregularly scattered blotches or sometimes con- fluent in transverse bands, lanceolate to lanceolate-attenuate, 30-50 × 8-9 cm; margin white, with pungent, brown teeth, 2-4 $\mathrm{mm}$ long, 10$15 \mathrm{~mm}$ apart. Inflorescence $1.00-1.25 \mathrm{~m}$ high, erect, 3-8-branched from above middle, lower branches rebranched. Racemes subcapitate to capitate, 6-12 cm long, dense, sometimes cylindric, slightly acuminate, up to $20 \mathrm{~cm}$ long, lax. Floral bracts $10-20 \mathrm{~mm}$ long. Pedicels $20-25 \mathrm{~mm}$ long. Flowers: perianth orange-red or occasionally yellow, usually glossy, 30-38 mm long, 8$10 \mathrm{~mm}$ across ovary, abruptly constricted above ovary to form globose basal swelling, widening and curving towards mouth, cylindric-trigonous; outer segments free for $10 \mathrm{~mm}$; stamens exserted to $1 \mathrm{~mm}$; style exserted to $2 \mathrm{~mm}$.

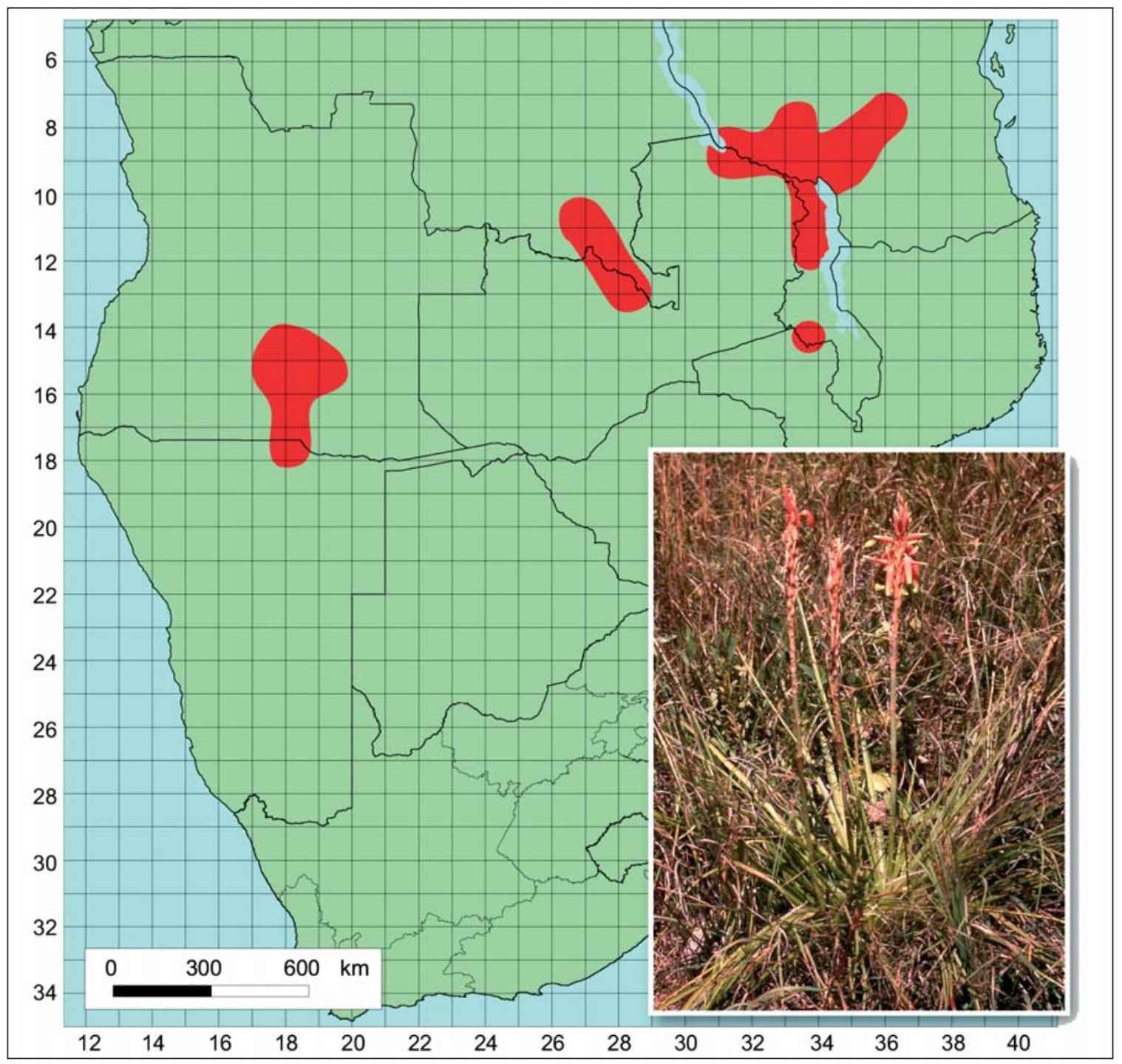

Figure 18. A. nuttii. 
Flowering time: March to May, or August and September.

Habitat: Grassland with scattered Acacia bushland on black cotton soils, on rocky places, often on hillsides.

Distinguishing characters: A. lateritia var. lateritia can be distinguished from other maculate aloes in Malawi (A. duckeri, A. greatheadii, A. menyharthii subsp. menyharthii and A. zebrina) by the following combination of characters: the glossy light green leaves with thin white margins and paler lower surface with fewer and more obscure, irregularly scattered blotches; subcapitate to capitate racemes with flowers that are glossy and bright orange-red or yellow; pedicels $20-25 \mathrm{~mm}$ long.

Conservation status: Critically Endangered; threatened by habitat degradation and urban expansion, resulting in small and fragmented subpopulations in Malawi.

Distribution: Occurs commonly in Tanzania and southeastern Kenya. Sighted only once in Malawi. Its occurrence in Malawi, south of the Songwe River, is possibly owing to collection or dispersal by humans, who often travel back and forth between Malawi and Tanzania on business (Figure 13). A. lateritia var. graminicola (Reynolds) S.Carter is not present in Malawi, but is restricted to western Kenya.

\section{Aloe mawii Christian}

Common names: chinthembwe (Chewa/Tumbuka); khuzi (Ngoni); lichongwe (Yao).

Description: Arborescent plant up to $2 \mathrm{~m}$ high, sometimes acaulescent. Stem 1-2 m long, stout, erect, simple to $1 \mathrm{~m}$, then sometimes sparingly branched above, sometimes decumbent with few suckers from base to form small groups; with persistent dried leaves. Leaves densely rosulate, spreading or erectly spreading, sometimes recurved, greyish green with bluish tinge, turning reddish when exposed, often bright green when young, usually without spots, with some spots when young, somewhat striate, lanceolate-ensiform, 40-60 × 8-10 cm; margin narrow, reddish, with pinkish orange teeth, 3-4 mm long, 7-14 mm apart. Inflorescence up to $1 \mathrm{~m}$ long, oblique, simple or 1-branched near raceme. Raceme longacuminate, 25-45 cm long, oblique to horizontal, dense; buds and flowers erectly secund. Floral bracts $1-2 \mathrm{~mm}$ long. Pedicel $4-6 \mathrm{~mm}$ long. Flowers: perianth red or orange, $20-40 \mathrm{~mm}$ long, $7 \mathrm{~mm}$ across ovary, gradually widening towards middle, gradually narrowed towards mouth, ventricose; outer segments free for $22 \mathrm{~mm}$; stamens and style exserted to $\pm 12 \mathrm{~mm}$.

Flowering time: May to June.
Habitat: Edge of precipice and on steep bare granite mountain slopes, also in open grassland on rocky mountain slopes.

Distinguishing characters: A. mawii is easily distinguished from other tall, single-stemmed aloes in Malawi (A. canis and A. excelsa var. breviflora) by its mostly simple, sometimes 1-branched, inflorescences with horizontal racemes and secund, red or orange flowers. A further distinguishing character is its dark to greyish green leaves with a bluish bloom, which are usually without spots. The stem of $A$. mawii is mostly simple up to $1 \mathrm{~m}$ in height, but can then sometimes be sparingly branched above, or occasionally decumbent with a few suckers from the base to form small groups. Conservation status: Vulnerable; threatened by habitat loss resulting in small and fragmented subpopulations in Malawi.

Distribution: Occurs in Malawi, southern Tanzania and central Mozambique (Figure 14).

${ }^{\mathrm{NE}}$ Aloe menyharthii Baker subsp. menyharthii Common names: manyesa, namanyesa, senjere (Lomwe); khuzi, mdyang'oma (Ngoni).

Description: Usually acaulescent plants, sometimes with decumbent stem of up to $1 \mathrm{~m}$ long; rosettes solitary or suckering to form small groups. Leaves densely rosulate, spreading, dark greyish to bright green, upper surface with copious elongated, white blotches, lower surface unmarked or obscurely to strongly lineate and usually without spots, lanceolate-attenuate, up to $95 \times 6-9 \mathrm{~cm}$, sometimes with 5-10 cm withered and twisted apical portion; margin white to dark brown, with pungent, red-brown teeth, $3-5 \mathrm{~mm}$ long, 5-25 $\mathrm{mm}$ apart. Inflorescence 1-2 $\mathrm{m}$ high, erect, up to 10-branched from above middle, lowest branches sometimes rebranched. Racemes capitate or capitate-corymbose, 3-6 $\mathrm{cm}$ long, rather dense. Floral bracts 10-30 mm long. Pedicels 15-25 mm long. Flowers: perianth coralred to pinkish scarlet, $25-35 \mathrm{~mm}$ long, $\pm 9 \mathrm{~mm}$ across ovary, constricted above ovary to form globose basal swelling, widening towards mouth, cylindric-trigonous, slightly decurved; outer segments free for $\pm 8 \mathrm{~mm}$; stamens and style slightly exserted.

Flowering time: May to August.

Habitat: Among grass in open bush and miombo woodland.

Distinguishing characters: A. menyharthii subsp. menyharthii is an extremely variable species. It can be distinguished from other maculate aloes in Malawi (A. duckeri, A. greatheadii, A. lateritia var. lateritia and A. zebrina) by the following combination of characters: the dark greyish to bright green leaves with white to dark brown margins, 
which are copiously spotted on the upper surface only; capitate to capitate-corymbose racemes with flowers that are coral-red to pinkish scarlet; pedicels $15-25 \mathrm{~mm}$ long. A further distinguishing character is the upper lateral racemes that are often level with or above the terminal one, whereas in other maculates in Malawi (except for A. duckeri) the terminal raceme is usually the longest.

Conservation status: Vulnerable; threatened by fire and general habitat loss resulting in small and fragmented subpopulations in Malawi.

Distribution: Near-endemic to Malawi and Mozambique; known only from southern and central Malawi and adjacent parts of the Tete Province in Mozambique (Figure 15). A. menyharthii subsp. ensifolia S.Carter is not present in Malawi, but is known only from a limited area in Mozambique.

General notes: This is a very variable taxon. Reynolds (1966) erroneously included it in A. swynnertonii Rendle.

Aloe myriacantha (Haw.) Schult. \& Schult.f. Common names: nyakaryayata (Ankole).

Description: Acaulescent grass aloe of $0.2-0.3 \mathrm{~m}$ high; rosettes solitary or suckering to form small groups. Leaves rosulate, erectly spreading, dull green, with few white spots towards base, with more copious somewhat tuberculate-subspinulescent spots on lower surface, narrowly linear, keeled, 25-40 × 0.8-1.0 cm; margin with minute white teeth, up to $0.5-1.0 \mathrm{~mm}$ long and $1-2 \mathrm{~mm}$ apart at base, smaller and more distant above. Inflorescence $0.20-0.25 \mathrm{~m}$ high, erect, simple. Racemes capitate, $\pm 4.5 \mathrm{~cm}$ long, dense. Floral bracts up to $20 \mathrm{~mm}$ long. Pedicels $10-25 \mathrm{~mm}$ long. Flowers: perianth dull reddish pink or purple, rarely greenish white, $\pm 20 \mathrm{~mm}$ long, 5-6 mm across ovary, not or only slightly narrowed above ovary, basally substipitate, cylindric-trigonous, mouth distinctly bilabiate, upturned; outer segments free; stamens and style exserted 0-1 mm. Flowering time: January to May or April.

Habitat: Among rocks in high-altitude grassland. Distinguishing characters: A. myriacantha can be distinguished from the other grass aloes in Malawi (A. buchananii and A. nuttii) by its rosettes that are usually solitary or suckering to form small groups, with rosulate, distinctly keeled leaves, as well as its capitate racemes with dull pinkish red flowers ( $\pm 20 \mathrm{~mm}$ long, 5-6 $\mathrm{mm}$ across ovary) with distinctly bilabiate, upturned mouth. Pedicels are 10-25 mm long.

Conservation status: Vulnerable; threatened in Malawi by habitat degradation and urban expansion, resulting in small and fragmented subpopulations in the country.

Distribution: This species has probably the widest distribution range of any aloe, with a north-south distribution range of over $5,000 \mathrm{~km}$. It occurs from the Humansdorp area in the Eastern Cape Province of South Africa, along the coast and northwards along the escarpment through western Swaziland to the Bosbokrand area in Mpumalanga, South Africa. It is also found further north on the border between Zimbabwe and Mozambique, in Malawi, and the Eastern Arc of mountains in Tanzania and Kenya, as well as Uganda, Burundi and Rwanda in southern Tropical Africa (Figure 16).

\section{Aloe mzimbana Christian}

Description: Acaulescent plants or with stem very short; rosettes $0.4 \mathrm{~m}$ across, suckering to form small to large dense groups. Leaves densely rosulate, spreading-incurved, grey to grey-green sometimes with reddish tinge, obscurely striate, usually without spots, sometimes with few scattered spots, ovate-lanceolate, 20-35 × 7-10 cm; margin reddish pink, with reddish pink teeth, 2-3 $\mathrm{mm}$ long, 8-10 $\mathrm{mm}$ apart. Inflorescences 0.3-0.8 m high, erect, simple or 2-4-branched from below middle. Racemes broadly cylindric to subcapitate, 8-15 cm long, dense. Floral bracts 6-10 mm long. Pedicels $15-20 \mathrm{~mm}$ long. Flowers: perianth coral-red to scarlet, $30-35 \mathrm{~mm}$ long, $8 \mathrm{~mm}$ across ovary, constricted above ovary, widening towards wide-open mouth, cylindric, slightly curved; outer segments free for $12 \mathrm{~mm}$; stamens exserted 0-1 $\mathrm{mm}$; style exserted 1-2 mm. Flowering time: June to July.

Habitat: Montane and watershed grassland, on rock-outcrops in miombo woodland.

Distinguishing characters: A. mzimbana is best distinguished from other acaulescent or very short stemmed aloes in Malawi by the combination of its dense, suckering rosettes of spreadingincurved, obscurely lineate, usually unspotted leaves with reddish pink margins and the simple or up to 3-branched inflorescence with dense broadly cylindric to subcapitate racemes, as well as the floral bracts $(6-10 \mathrm{~mm})$ that are about half as long as the pedicels (15-20 $\mathrm{mm}$ ).

Conservation status: Vulnerable; threatened in Malawi by habitat loss and over-collecting for medicinal use.

Distribution: Rather widespread in southeastern Democratic Republic of the Congo, southern Tanzania, Malawi and northeastern Zambia (Figure 17). 
Aloe nuttii Baker

Common names: tembwisya (Mambwe); iwata (Namwanga); nibeets (Uhehe); dilenga (DRCongo, uncertain).

Description: Grass aloe, growing singly or with up to 12 and more tufted stems. Stems very short or up to $0.2 \mathrm{~m}$ long, erect. Leaves rosulate, erectly spreading, sometimes deflexed at about middle, green, upper surface sometimes obscurely lineate, usually with few pale spots near base, lower surface usually copiously spotted near base, spots occasionally spinulescent, grass-like and subfleshy, linear, keeled, $40-50 \mathrm{~cm}$ long, up to $4 \mathrm{~cm}$ at dilated base, abruptly narrowed to $1.5-2.0 \mathrm{~cm}$, tapering towards apex; margin very narrow, white, with densely crowded, minute, white, soft teeth, up to $1 \mathrm{~mm}$ long. Inflorescence $0.6-0.8 \mathrm{~m}$ high, erect, unbranched. Raceme cylindrical- acuminate, 15-20 cm long, dense; buds entirely covered by large imbricate bracts. Floral bracts 15-25 mm long. Pedicels 25-35 mm long. Flowers: perianth coral-pink to orange-red with green tips, 35-42 $\mathrm{mm}$ long, 7-9 $\mathrm{mm}$ across ovary, not narrowed above ovary, cylindrical-trigonous, base tapering into pedicel; outer segments free almost to base or for $3 / 4$ of length; stamens not exserted; style exserted 0-1 $\mathrm{mm}$.

Flowering time: January to March, depending on locality and rainfall.

Habitat: Montane and dambo grassland, often on rocky slopes.

Distinguishing characters: $A$. nuttii can be distinguished from the other grass aloes in Malawi (A. buchananii and A. myriacantha) by its rosettes that are sometimes solitary or with up to 12 and more tufted stems, with rosulate, keeled leaves,

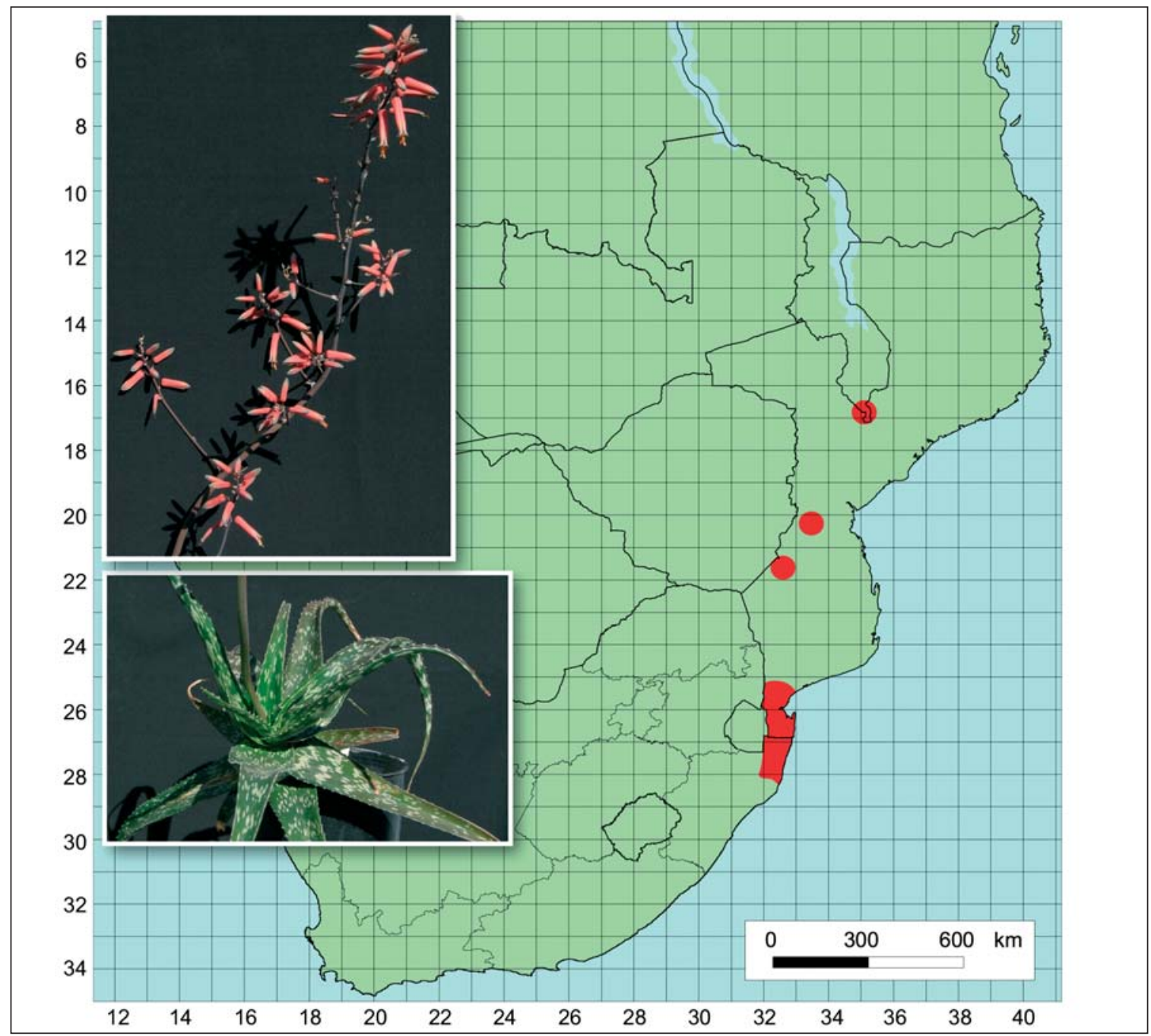

Figure 19. A. suffulta. 
as well as its cylindrical-acuminate racemes with coral-pink to orange-red flowers (35-42 $\mathrm{mm}$ long, 7-9 $\mathrm{mm}$ across ovary), with a non-bilabiate mouth. Pedicels are $25-35 \mathrm{~mm}$ long.

Conservation status: Vulnerable; threatened in Malawi by habitat loss due to over-grazing and fire.

Distribution: Widespread in southeastern Angola (Cuando-Cubango), southern Democratic Republic of the Congo, Malawi, southwestern Tanzania and northern Zambia (Figure 18).

\section{Aloe suffulta Reynolds}

Common names: climbing-flower aloe.

Description: Solitary plants or suckering to form dense groups. Stem 0.1-0.2 m long, decumbent, with persistent dried leaves. Leaves cauline dispersed, spreading and recurved, dark glossy green, with dull white spots, spots sometimes irregularly scattered, usually more or less arranged in series of interrupted undulating transverse bands, larger and more confluent on lower surface, narrowly deltoid, gradually attenuate, 30-50 × 2.5$4.0 \mathrm{~cm}$; sheath 5-10 $\mathrm{mm}$ long, striatulate, light green; margin sometimes whitish, with whitish teeth, 1-2 $\mathrm{mm}$ long, 5-10 $\mathrm{mm}$ apart. Inflorescence up to $2 \mathrm{~m}$ high, twining, supported by shrubs, up to 9-branched from well above middle. Racemes cylindric, slightly acuminate, terminal the longest at $\pm 15 \mathrm{~cm}$ long, lateral $\pm 8 \mathrm{~cm}$ long, lax. Floral bracts 4-6 $\mathrm{mm}$ long. Pedicels 7-10 mm long. Flowers: perianth salmon-pink, whitish at mouth, $25-35 \mathrm{~mm}$ long, $\pm 6 \mathrm{~mm}$ across ovary, slightly narrowed above ovary, enlarging towards wide-open mouth, slightly curved, cylindric-trigonous; outer segments free for $7 \mathrm{~mm}$; stamens exserted to $6 \mathrm{~mm}$; style exserted to $8 \mathrm{~mm}$. Flowering time: June to July.

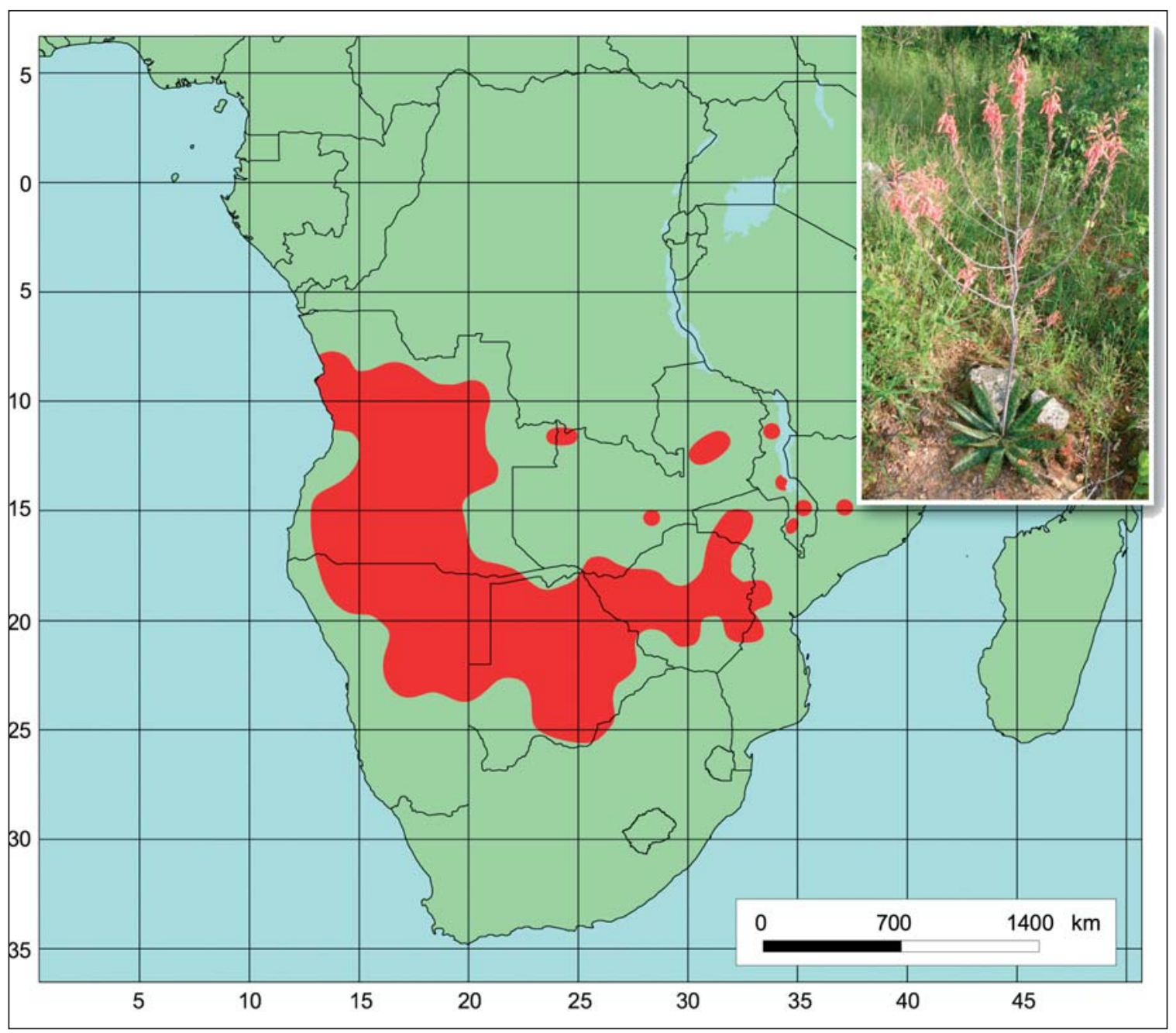

Figure 20. A. zebrina. 
Habitat: In shade under bushes, in sand with loose humus, on black cotton clays or on termite mounds, in very hot places. Very susceptible to cold.

Distinguishing characters: A. suffulta is easily distinguished from other Malawian aloes by its cauline dispersed, green, spotted leaves with distinctly visible, striatulate sheaths, as well as its slender, climbing inflorescence that is supported by surrounding bushes.

Conservation status: Critically Endangered; threatened in Malawi by habitat degradation and urban expansion, resulting in small and fragmented subpopulations in the country.

Distribution: Occurs in the extreme south of Malawi, in southern Zimbabwe, western and southern Mozambique and northern parts of the KwaZuluNatal province of South Africa (Figure 19).

General notes: Known in Malawi from one locality only. The species was discussed in detail by Smith \& Crouch (2001).

\section{Aloe zebrina Baker}

Common names: zebra-leaf aloe; /ganya (!ho); chinthembwe (Chewa/Tumbuka); sankulu (Kikongo); edundu (Kwanyama); //noru, //nuru, /gikwe (Narõ); okandala-kazengue (Umbundu); lichongwe (Yao).

Description: Acaulescent plants; rosettes erect, sometimes solitary or usually suckering to form groups. Leaves densely rosulate, spreading, dull green, sometimes rich brown in dry conditions, upper surface with transverse bands of conspicuous, whitish, oblong spots, lower surface usually obscurely or copiously spotted, lanceolate, usually dried and twisted at apex, 15-35 × 6-10 cm; margin with stout, pungent, red-brown teeth, $4-7 \mathrm{~mm}$ long, 10-15 mm apart. Inflorescence $0.75-2.00 \mathrm{~m}$ high, erect, 4-12-branched from above middle, lower branches often rebranching. Racemes narrowly cylindrical-acuminate, 30-40 cm long, dense to very lax. Floral bracts $6-15 \mathrm{~mm}$ long. Pedicels $6-15 \mathrm{~mm}$ long. Flowers: perianth dull red to pinkish red or coral-coloured, 25-35 mm long, 7-9 $\mathrm{mm}$ across ovary, abruptly constricted just above ovary to form globose basal swelling, widening towards mouth, slightly decurved, cylindrical-trigonous; outer segments free for 7-11 mm; stamens and style exserted to $2 \mathrm{~mm}$.

Flowering time: (November) February to April (May).

Habitat: Variety of veld types and soil, mostly grassland and thickets on dry hills and abundant in open Colophospermum mopane woodland.

Distinguishing characters: A. zebrina is an extremely variable species. It can be distinguished from other maculate aloes in Malawi (A. duckeri, A. greatheadii, A. lateritia var. lateritia and A. menyharthii subsp. menyharthii) by the following combination of characters: the dull green leaves that sometimes turn a rich brown in dry conditions and that are variedly spotted on the lower surface; narrowly cylindrical-acuminate racemes with flowers that are dull red to pinkish red; pedicels $6-15 \mathrm{~mm}$ long. It is also the only maculate aloe flowering as early as November, with a definite predominance for flowering in summer (the Malawian rainy season).

Conservation status: Endangered; threatened in Malawi by its small distribution range, fragmented populations, habitat loss and overcollection for medicinal use.

Distribution: Widespread in Angola (Bengo, Cuando-Cubango, Cuanza Sul, Cunene, Huambo, Húla, Malange, Moxico), northern Namibia, Botswana, Zambia, Zimbabwe, Malawi, western Mozambique and just enters northwestern South Africa (North West province) on the border with Botswana (Figure 20).

\section{Acknowledgements}

Ms Hester Steyn of the National Herbarium, South African National Biodiversity Institute, Pretoria, is thanked for producing the base maps that were used to create the distribution maps. An anonymous referee is thanked for suggesting improvements to the manuscript. Photographic credits: A. lateritia var. lateritia, A. nuttii-S. Carter; A. chabaudii var. chabaudii, A. cryptopoda, A. greatheadii, A. myriacantha-M. J. Kimberley; A. bulbicaulis - R. R. Klopper; A. arborescens, A. buchananii, A. cameronii var. cameronii, A. cameronii var. dedzana, A. canis, A. chabaudii var. mlanjeana, A. menyharthii subsp. menyharthii, A. mzimbana-S. S. Lane; A. christianii, A. duckeri, A. excelsa var. breviflora, A. mawiiL. C. Leach; A. suffulta - J. B. Miller; A. zebrinaE. J. van Jaarsveld.

\section{References}

BAKER, J.G. (1895). Decades Kewenses. Plantarum Novarum in Herbario Horti Regii Conservatarum. Decades XV.-XIX. Bull. Misc. Inform., Kew 1895: 102-120.

Burrows, J.E. \& Willis, C.K. (eds.) (2005). Plants of the Nyika Plateau: an account of the vegetation of the Nyika National Parks of Malawi and Zambia. Southern African Botanical Diversity Network Report No. 31. SABONET, Pretoria.

Carter, S. (1994). Aloaceae. In Polhill, R.M. (ed.), Flora of Tropical East Africa. Balkema, Rotterdam.

Carter, S. (2001). Aloaceae. In Pope, G.V. (ed.), Flora Zambesiaca 12 (3): 48-98. 
Carter, S., Lavranos, J.J., Newton, L.E. \& WaLKer, C.C. (2011). Aloes: The definitive guide. Kew Publishing, Royal Botanic Gardens, Kew / British Cactus \& Succulent Society.

Chapman, J.D. \& White, F. (1970). The evergreen forests of Malawi. Commonwealth Forestry Institute, Oxford.

Christian, H.B. (1938). Aloe chabaudi var. mlanjeana. Flow. Pl. S. Afr. 18: t. 698.

Christian, H.B. (1940). Some new Aloe species from central and east tropical Africa. J. S. Afr. Bot. 6: 177-190.

CITES. (2010). CITES Appendices I, II and III. http://www.cites.org/eng/app/appendices.shtml (accessed: May 2010).

Dowsett-Lemaire, F. (2001a). The chorology of the forest flora. In WHITE, F., DowsETTLemaire, F. \& Chapman, J.D., Evergreen forest flora of Malawi. Royal Botanic Gardens, Kew.

Dowsett-Lemaire, F. (2001b). A synopsis of the vegetation of Malawi. In White, F., DowsetTLemaire, F. \& Chapman, J.D., Evergreen forest flora of Malawi. Royal Botanic Gardens, Kew.

EXELL, A.W. (1960). History of botanical collecting in the Flora Zambesiaca area. In Exell, A.W. \& Wild, H. (eds.), Flora Zambesiaca 1: 23-34. Crown Agents for Overseas Governments and Administrations, London.

GILLETT, J.B. (1962). The botanical exploration of the area of the Flora of Tropical East Africa (Uganda, Kenya, Tanganyika and Zanzibar). In Fernandes, A., Competes Rendus de la IVe Réunion Plénière de l'Association pour l'Étude Taxonomique de la Flore d'Afrique Tropicale: 205-229. Lisboa.

Glen, H.F. \& HaRdy, D.S. (2000). Aloaceae (First part): Aloe. In GERMISHUIZEN, G. (ed.), Flora of Southern Africa Vol. 5, Part 1, Fascicle 1: 1-167. National Botanical Institute, South Africa.

Hemsley, J.H. (1903). Aloe cameroni. Curt. Bot. Mag. 129: t. 7915.

IUCN. (1994). IUCN Red List Categories. Prepared by the IUCN Species Survival Commission. IUCN, Gland, Switzerland.

Lane, S.S. (2001). A new Aloe in Malawi. Aloe 38: $72-73$.

LANE, S.S. (2004). A field guide to the aloes of Malawi. Umdaus Press, Hatfield.
Lane, S.S., Smith, G.F. \& Steyn, E.M.A. (2003). Validation and amendment of the name Aloe canii. Aloe 40: 55.

Msekandiana, G. \& Mlangeni, E. (2002). Malawi. In Golding, J. (ed.), Southern African Plant Red Data Lists. Southern African Botanical Diversity Network Report No 14: 31-42. SABONET, Pretoria.

REUTERs. (2009). Malawi could be the cradle of humankind: researcher. Africa: The Good News 26 October 2009. http://www.africa goodnews.com/brand-africa/lessons-fromafrica/1063-malawi-could-be-the-cradle-of-hu mankind-esearcher.html (accessed September 2011).

ReynolDS, G.W. (1954). The aloes of Nyasaland. The Nyasaland Society and African Book Centre of Nyasaland.

REynolDS, G.W. (1965). A new aloe variety from Malawi. J. S. Afr. Bot. 31: 167-168.

REYNOLDS, G.W. (1966). The aloes of tropical Africa and Madagascar. Aloes Book Fund, Mbabane.

Smith, G.F. \& Crouch, N.R. (2001). Aloe suffulta. Flow. Pl. Afr. 57: 16-22, t. 2163.

Smith, G.F., Klopper, R.R. \& Crouch, N.R. (2008). Aloe arborescens Mill. (Asphodelaceae: Alooideae) and CITES. Haseltonia 14: 189-198.

Smith, G.F., Walters, M., Klopper, R.R. \& Crouch, N.R. (2008). Aloes of the World: African Plants Initiative. An international web-based collaboration to promote scholarly research on Aloe L. Bradleya 26: 111-119.

THe World FACT Book. (2010). https:// www.cia.gov/library/publications/the-worldfactbook/geos/mi.html (accessed: May 2010).

Verdoorn, I.C. \& Christian, H.B. (1941). Aloe mzimbana. Flow. Pl. S. Afr. 21: t. 838.

White, F. (1962). A history of plant collecting in Northern Rhodesia. In Fernandes, A., Competes Rendus de la IVe Réunion Plénière de l'Association pour l'Étude Taxonomique de la Flore d'Afrique Tropicale: 175-203. Lisboa.

WiLLD, H. (1962). Biographical notes on botanical collectors in the Federation of Rhodesia and Nyasaland. In Fernandes, A., Competes Rendus de la IVe Réunion Plénière de l'Association pour l'Étude Taxonomique de la Flore d'Afrique Tropicale: 161-173. Lisboa. 